\title{
Anthocyanins: Biosynthesis, Distribution, Ecological Role, and Use of Biostimulants to Increase Their Content in Plant Foods-A Review
}

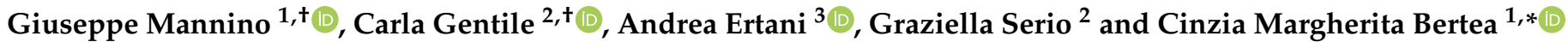 \\ 1 Department of Life Sciences and Systems Biology, Plant Physiology Unit, University of Turin, \\ Via Quarello 15/A, 10135 Turin, Italy; giuseppe.mannino@unito.it \\ 2 Department of Biological, Chemical and Pharmaceutical Sciences and Technologies (STEBICEF), \\ University of Palermo, Viale delle Scienze, 90128 Palermo, Italy; carla.gentile@unipa.it (C.G.); \\ graziella.serio01@unipa.it (G.S.) \\ 3 Department of Agricultural, Forest, and Food Sciences, University of Turin (DISAFA), Largo Paolo Braccini 2, \\ 10095 Grugliasco, Italy; andrea.ertani@unito.it \\ * Correspondence: cinzia.bertea@unito.it; Tel.: +39-011-670-6361 \\ + These authors contributed equally to this work.
}

Citation: Mannino, G.; Gentile, C.; Ertani, A.; Serio, G.; Bertea, C.M. Anthocyanins: Biosynthesis, Distribution, Ecological Role, and Use of Biostimulants to Increase Their Content in Plant Foods-A Review. Agriculture 2021,11, 212. https:// doi.org/10.3390/agriculture11030212

Academic Editor: Mercè Llugany

Received: 9 February 2021

Accepted: 1 March 2021

Published: 5 March 2021

Publisher's Note: MDPI stays neutral with regard to jurisdictional claims in published maps and institutional affiliations.

Copyright: () 2021 by the authors. Licensee MDPI, Basel, Switzerland. This article is an open access article distributed under the terms and conditions of the Creative Commons Attribution (CC BY) license (https:// creativecommons.org/licenses/by/ $4.0 /)$

\begin{abstract}
In the past century, plant biostimulants have been increasingly used in agriculture as innovative and sustainable practice. Plant biostimulants have been mainly investigated as potential agents able to mitigate abiotic stress. However, few information is available about their ability to influence fruit quality or change fruit phytochemical composition. In particular, very little is known about their effects on anthocyanin synthesis and accumulation. Due to the increasing demand of consumers for healthier foods with high nutraceutical values, this review tries to fill the gap between anthocyanin content and biostimulant application. Here, we elucidate the chemical structure, biosynthetic pathway, plant distribution, and physiological role of anthocyanins in plants. Moreover, we discuss the potential implications for human health derived from the consumption of foods rich in these molecules. Finally, we report on literature data concerning the changes in anthocyanin content and profile after the application of biostimulant products on the most common anthocyanin-containing foods.
\end{abstract}

Keywords: anthocyanidins; sustainable agriculture; fruit quality; nutraceuticals; antioxidant activity; phytochemicals; meta-analysis; bibliometric analysis

\section{Introduction}

Over the past years, the use of chemical fertilizers as agronomic practice has strongly increased with the aim to enhance the food production and meet the global needs caused by an exponential growth of the population [1,2]. However, despite a big increment of the production that can be easily obtained after the application of chemical fertilizers, their uncontrolled use could cause different and severe problems, including global climate change, environmental pollution, and loss in the quality of the production [3]. In order to reduce these problems, the latest agronomic research lines are looking for more sustainable alternatives, which can be useful not only to limit the dependence from chemical fertilizers together to the adverse consequences caused by their application, but also to maintain or even improve the production quality [4].

In this context, plant biostimulants are actually considered a sustainable strategy to enhance crop yield under either optimal or stress conditions, since they may partially reduce chemical fertilizers $[5,6]$. Moreover, differently from chemical fertilizers, biostimulants are products based on natural substances often originating from food and/or industrial wastes, hence they may also strongly contribute to the circular economy aspects $[7,8]$. At the beginning, the effects derived from the application of biostimulants were exclusively 
studied by monitoring plants under abiotic stresses, and evaluating their improvement in tolerance mechanisms [2,9-13]. Among the studied parameters, the attention was almost exclusively focused on plant physiological parameters, such as the morphological aspects, pigment content, or photosynthesis and photorespiration efficiency [14-16]. On the other hand, only a limited number of experiments were addressed to the quality of fruits produced by plants treated with biostimulants, and in particular mostly were related to the evaluation of few pomological parameters, such as size, weight, yield, and color of the produced fruits $[17,18]$. Consequently, the biostimulant effects on nutritional and nutraceutical attributes were and are still quite unexplored [1].

However, the consumer growing interest in healthy foods encouraged also the study of the parameters related to nutritional and nutraceutical aspects of foods derived from plant treated with biostimulants [1,19]. In particular, the current epidemiological emergency caused by SARS-CoV-2 has contributed to a change in food consumption all over the world, by increasing consumer attention not only for the origin of the raw materials, but also for the potential health benefits [19]. Moreover, the high incidence of obesity, cancer, and diabetes at global level, highlights the strong relationship between food-intake and long-term health effects [20,21], encouraging the consumption of foods rich in bioactive compounds [22]. Among them, red-black colored fruits are now receiving increasing attention due to their significant amounts of anthocyanins and anthocyanidins, compounds able to exert a wide range of biological and pharmacological properties, including antioxidant, antimicrobial, anti-inflammatory, anticancer, antidiabetic, and antiatherosclerotic activity [22]. The aims of this review are: (i) To elucidate the chemical structure, biosynthesis mechanism, plant distribution, and physiological role of anthocyanins in plants; (ii) to investigate the potential implications for human health due to consumption of foods rich in anthocyanins; (iii) to report information concerning the changes in anthocyanin content and profile following the application of biostimulant products on the most common anthocyanin-containing foods.

\section{Anthocyanidins and Anthocyanins}

\subsection{Chemical Structures and Classification}

Anthocyanidins are colored molecules having medium-size and belonging to the class of flavonoids [23]. Actually, 25 different anthocyanidins are known (Figure 1), that differ from each other for the presence of hydroxyl $(-\mathrm{OH})$ and methoxy $\left(-\mathrm{OCH}_{3}\right)$ groups bound at the scaffold core (Figure 1) [24]. Consequently, anthocyanidins are grouped into 3-hydroxyanthocyanidins, 3-deoxyanthocyanidins, and O-methylated anthocyanidins. Cyanidin (Cy), Delphinidin (Dp), Pelargonidin (Pg), three among the non-methylated anthocyanidins, are the most common in nature. In particular, it was estimated that $50 \%$ of plants producing anthocyanidins have $\mathrm{Cy}, 12 \%$ have $\mathrm{Dp}$, and $10 \%$ have $\mathrm{Pg}[25,26]$. Peonidin $(\mathrm{Pn})$, Malvidin (Mv), and Petunidin (Pt), belonging to the methylated anthocyanidins, can be also easily found in plants $[25,26]$.

In most of the cases, anthocyanidins are bounded with sugar moieties, forming the corresponding anthocyanins. Glycosylation is achieved enzymatically following the adding of the sugar portion at the 3rd and/or 5th position $\left(R_{1}\right.$ and/or $R_{2}$ subsistent of the chemical structure displayed in Figure 1 of the scaffold $[27,28]$. As a consequence of the glycosylation, anthocyanins have an increased water solubility and stability with respect to the related anthocyanidins [28]. Despite the most common glycosylation process involves the condensation of monosaccharides such as glucose, galactose, rhamnose, arabinose, rutinose and xylose, also disaccharides and trisaccharides may be attached in some cases [23]. Finally, anthocyanins may be also often acylated with organic acids such as p-coumaric, caffeic, and ferulic acids via ester bonds usually to the 3-position of the sugar moiety [23,27]. Consequently, to date more than 500 different anthocyanins that differ not only for the glycosylation pattern of the scaffold, but also for the presence and position of aliphatic or aromatic carboxylates are reported. In spite of their great structure variability, the anthocyanins most distributed in plants are those originated by $\mathrm{Cy}, \mathrm{Dp}$, 
and Pg. They are present in $80 \%$ of the leaves, $69 \%$ of the fruits, and $50 \%$ of the colored flowers $[19,25,26,29,30]$. On the other hand, anthocyanins formed by Pt, Mv, and Pn, are limitedly distributed $[19,25,26,29-31]$.<smiles></smiles>

\begin{tabular}{|c|c|c|c|c|c|c|c|c|}
\hline \multirow{2}{*}{ Name } & \multirow{2}{*}{ Abbreviations } & \multicolumn{7}{|c|}{ Substitution pattern } \\
\hline & & R1 & $\mathbf{R 2}$ & R3 & R4 & R5 & R6 & R7 \\
\hline Apigeninidin & Ap & $\mathrm{H}$ & $\mathrm{OH}$ & $\mathrm{H}$ & $\mathrm{OH}$ & $\mathrm{H}$ & $\mathrm{OH}$ & $\mathrm{H}$ \\
\hline Arrabidin & $A b$ & $\mathrm{H}$ & $\mathrm{H}$ & $\mathrm{OH}$ & $\mathrm{OH}$ & $\mathrm{H}$ & $\mathrm{OH}$ & $\mathrm{OMe}$ \\
\hline Aurantinidin & $\mathrm{Au}$ & $\mathrm{OH}$ & $\mathrm{OH}$ & $\mathrm{OH}$ & $\mathrm{OH}$ & $\mathrm{H}$ & $\mathrm{OH}$ & $\mathrm{H}$ \\
\hline Capensinidin & $\mathrm{Cp}$ & $\mathrm{OH}$ & OMe & $\mathrm{H}$ & $\mathrm{OH}$ & OMe & $\mathrm{OH}$ & $\mathrm{OMe}$ \\
\hline Carajurin & $\mathrm{Cj}$ & $\mathrm{H}$ & $\mathrm{H}$ & $\mathrm{OH}$ & $\mathrm{OH}$ & $\mathrm{H}$ & Ome & $\mathrm{OMe}$ \\
\hline Cyanidin & Cy & $\mathrm{OH}$ & $\mathrm{OH}$ & $\mathbf{H}$ & $\mathrm{OH}$ & $\mathrm{OH}$ & $\mathrm{OH}$ & H \\
\hline Delphinidin & Dp & $\mathrm{OH}$ & OH & $\mathbf{H}$ & $\mathrm{OH}$ & OH & $\mathrm{OH}$ & $\mathrm{OH}$ \\
\hline Europinidin & $\mathrm{Eu}$ & $\mathrm{OH}$ & OMe & $\mathrm{H}$ & $\mathrm{OH}$ & OMe & $\mathrm{OH}$ & $\mathrm{OH}$ \\
\hline Hirsutidin & $\mathrm{Hs}$ & $\mathrm{OH}$ & $\mathrm{OH}$ & $\mathrm{H}$ & $\mathrm{OMe}$ & $\mathrm{OMe}$ & $\mathrm{OH}$ & $\mathrm{OMe}$ \\
\hline 30-HydroxyAb & $3^{\prime} \mathrm{OHAb}$ & $\mathrm{H}$ & $\mathrm{H}$ & $\mathrm{OH}$ & $\mathrm{OH}$ & $\mathrm{OH}$ & $\mathrm{OH}$ & $\mathrm{OMe}$ \\
\hline 6-HydroxyCy & $60 \mathrm{HCy}$ & $\mathrm{OH}$ & $\mathrm{OH}$ & $\mathrm{OH}$ & $\mathrm{OH}$ & $\mathrm{OH}$ & $\mathrm{OH}$ & $\mathrm{OH}$ \\
\hline 6-HydroxyDp & $60 H D p$ & $\mathrm{OH}$ & $\mathrm{OH}$ & $\mathrm{OH}$ & $\mathrm{OH}$ & $\mathrm{OH}$ & $\mathrm{OH}$ & $\mathrm{OH}$ \\
\hline 6-HydroxyPg & $60 \mathrm{HPg}$ & $\mathrm{OH}$ & $\mathrm{OH}$ & $\mathrm{OH}$ & $\mathrm{OH}$ & $\mathrm{H}$ & $\mathrm{OH}$ & $\mathrm{H}$ \\
\hline Luteolin & $\mathrm{Lt}$ & $\mathrm{H}$ & $\mathrm{OH}$ & $\mathrm{H}$ & $\mathrm{OH}$ & $\mathrm{OH}$ & $\mathrm{OH}$ & $\mathrm{H}$ \\
\hline Malvidin & Mv & $\mathrm{OH}$ & $\mathrm{OH}$ & H & $\mathrm{OH}$ & OMe & $\mathrm{OH}$ & OMe \\
\hline 5-MethylCy & 5-MCy & $\mathrm{OH}$ & OMe & $\mathrm{H}$ & $\mathrm{OH}$ & $\mathrm{OH}$ & $\mathrm{OH}$ & $\mathrm{H}$ \\
\hline Pelargonidin & $\mathrm{Pg}$ & $\mathrm{OH}$ & $\mathrm{OH}$ & H & $\mathrm{OH}$ & H & $\mathrm{OH}$ & H \\
\hline Peonidin & Pn & $\mathrm{OH}$ & $\mathrm{OH}$ & $\mathbf{H}$ & $\mathrm{OH}$ & OMe & $\mathrm{OH}$ & H \\
\hline Petunidin & Pt & OH & Он & H & он & OMe & $\mathrm{OH}$ & $\mathrm{OH}$ \\
\hline Pulchellidin & $\mathrm{PI}$ & $\mathrm{OH}$ & OMe & $\mathrm{H}$ & $\mathrm{OH}$ & $\mathrm{OH}$ & $\mathrm{OH}$ & $\mathrm{OH}$ \\
\hline Riccionidin-A & RiA & $\mathrm{OH}$ & $\mathrm{H}$ & $\mathrm{OH}$ & $\mathrm{OH}$ & $\mathrm{H}$ & $\mathrm{OH}$ & $\mathrm{H}$ \\
\hline Rosinidin & Rs & $\mathrm{OH}$ & $\mathrm{OH}$ & $\mathrm{H}$ & $\mathrm{OMe}$ & $\mathrm{OMe}$ & $\mathrm{OH}$ & $\mathrm{H}$ \\
\hline Tricetinidin & $\operatorname{Tr}$ & $\mathrm{H}$ & $\mathrm{OH}$ & $\mathrm{H}$ & $\mathrm{OH}$ & $\mathrm{OH}$ & $\mathrm{OH}$ & $\mathrm{OH}$ \\
\hline Rosinidin & Rs & $\mathrm{OH}$ & $\mathrm{OH}$ & $\mathrm{H}$ & $\mathrm{OMe}$ & $\mathrm{OMe}$ & $\mathrm{OH}$ & $\mathrm{H}$ \\
\hline Tricetinidin & $\mathrm{Tr}$ & $\mathrm{H}$ & $\mathrm{OH}$ & $\mathrm{H}$ & $\mathrm{OH}$ & $\mathrm{OH}$ & $\mathrm{OH}$ & $\mathrm{OH}$ \\
\hline
\end{tabular}

Figure 1. Chemical scaffold of anthocyanin compounds and their relative substituents. In the table, the most common anthocyanidins are reported in bold.

The conjugated bonds in the chemical scaffold are one of the responsible factors for the light absorption at about $500 \mathrm{~nm}[27,32]$. However, also the type of substituents present in the benzyl ring, local $\mathrm{pH}$, state of aggregation and complexation with other inorganic and organic molecules may contribute to color variation. In particular, it has been observed that anthocyanins may display almost the chromatic scale $[27,32,33]$.

\subsection{Biosynthesis}

Anthocyanidins and anthocyanins are almost exclusively produced by plants, in a branch of the phenylpropanoid pathway that is also involved in the biosynthesis of other flavonoids [34,35] (Figure 2). The enzymes involved in biosynthesis of anthocyanidins are localized in the endoplasmic reticulum, organized into a multi-enzyme complex named flavonoid metabolon $[34,35]$. The precursor for the synthesis of all flavonoids is the phenylalanine. This amino acid marks the branch point of primary and secondary metabolism from which the phenyl-propanoid pathway can lead to the 
synthesis of all phenolic compounds [34]. As first step of the pathway, phenylalanine is converted by phenylalanine ammonia-lyase (PAL) in cinnamic acid, which is then further transformed into coumaric acid by the action of cinnamic acid 4-hydroxylase $(\mathrm{C} 4 \mathrm{H})$. Following the activation catalyzed by the 4-coumarate-CoA ligase (4CL), 4-coumaryl-CoA reacts with three molecules of malonyl-CoA in a reaction catalyzed by chalcone synthase (CHS). This reaction allows the formation of 4-hydroxychalcone (ex. naringenin chalcone) and it marks the start of the flavonoid biosynthetic pathway. The 4-hydroxychalcone is transformed into the respective $7,3^{\prime}, 5^{\prime}$, trihydroxyl-flavone (ex. naringenin) by the action of chalcone isomerase (CHI). Afterwards, flavanone 3-hydroxylase (F3H) oxidizes $7,3^{\prime}, 5^{\prime}$, trihydroxyl-flavone into flavonol-form (ex. dihydrokaempferol). Then, dihydrokaempferol is transformed into dihydromyricetin or dihydroquercetin by the action of flavonoid $3^{\prime}$-hydroxylase $\left(\mathrm{F}^{\prime} \mathrm{H}\right)$ or flavonoid $3^{\prime}, 5^{\prime}$-hydroxylase $\left(\mathrm{F}^{\prime} 5^{\prime} \mathrm{H}\right)$, respectively. In order to convert the three hydroflavonols into anthocyanidins, the combined action of dihydroflavonol-4-reductase (DFR) and anthocyanidin synthase (ANS) is required. The first enzyme yields to the formation of the leucoanthocyanidins, meanwhile the second one catalyzes the 2-oxoglutaratedependent oxidation of each leucoanthocyanidin into 2-flavan-3,4-diol. These latter compounds spontaneously evolve to the respective anthocyanidins [36,37].

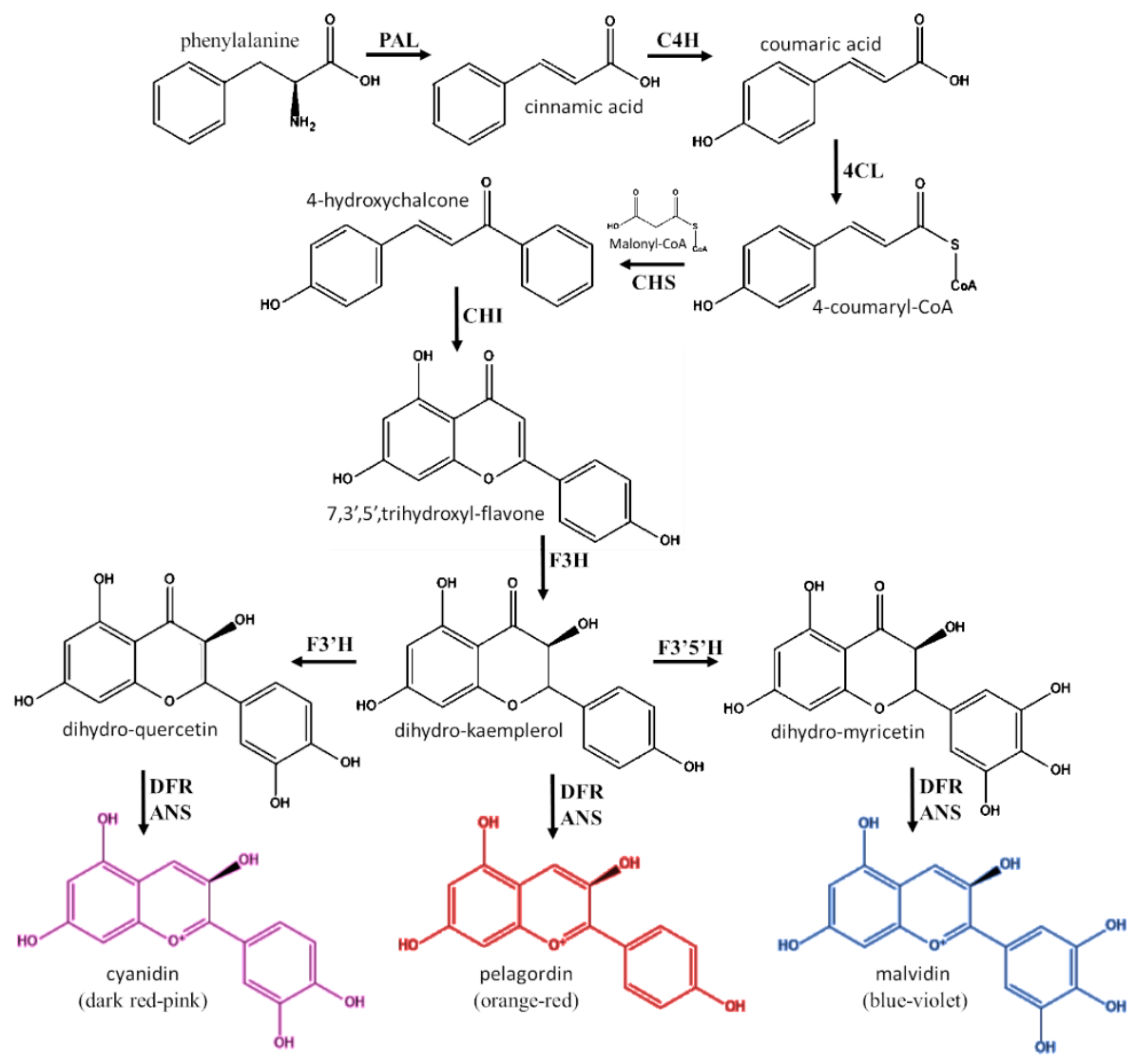

Figure 2. Biochemical pathway for the synthesis of anthocyanidins. PAL: phenylalanine ammonialyase; $\mathrm{C} 4 \mathrm{H}$ : cinnamic acid 4-hydroxylase; 4CL: 4-coumarate-CoA ligase; $\mathrm{CHS}$ : chalcone synthase; $\mathrm{CHI}$ : chalcone isomerase; $\mathrm{F} 3 \mathrm{H}$ : flavanone 3-hydroxylase; $\mathrm{F}^{\prime} \mathrm{H}$ : flavonoid $3^{\prime}$-hydroxylase; $\mathrm{F}^{\prime} 5^{\prime} \mathrm{H}$ : flavonoid 3',5'-hydroxylase; DFR: dihydroflavonol reductase; ANS: anthocyanidin synthase (ANS).

After their synthesis, anthocyanins are transported to the plant vacuole through vesicle trafficking pathway that may involve, or not, Golgi apparatus [38]. In vacuole, anthocyanidins are converted into the more stable form by the action of UDP-glucose flavonoid 3-Oglucosyltransferase (UF3GT) or UDP-glucose flavonoid 5-O-glucosyltransferase (UF5GT). These two enzymes add a sugar moiety respectively at the 3rd and/or 5th position $\left(\mathrm{R}_{1}\right.$ 
and/or $R_{2}$ subsistent of the chemical structure displayed in Figure 1 of the chemical scaffold $[27,28,36]$. Finally, the glucoside form of anthocyanidins may be further modified in many species by glycosylation, methylation, acylation, or condensation with other organic molecules [36,37].

\subsection{Role in Plants}

Anthocyanins are one of the major groups of natural pigments and they are responsible for colors of many leaves, flowers, and fruits [39]. In the past the physiological role of anthocyanins in plants was exclusively ascribed to improve the reproductive success by facilitating communication between plants and pollinators or seed-dispersers [40]. On the other hand, in order to justify the occurrence of anthocyanins also in plant districts different from flowers and fruits, it was mistakenly assumed that they could be an incidental consequence of the flavonoid pathway [41]. Indeed, the intermediate compounds dihydrokaempferol, dihymyricetin, and dihyquercetin may alternatively be oxidized into respective flavon-3-ols by flavonol synthase (FLS) as well as used for the production of anthocyanins (Figure 3) [27,29]. However, it was shown that some parts of the plants devoid of immediate signaling function contained a considerable amount of these flavonoids $[27,42,43]$. On the other hand, anthocyanins have specific histological localization, and their accumulation patterns do not match those of other pigments [27,44].

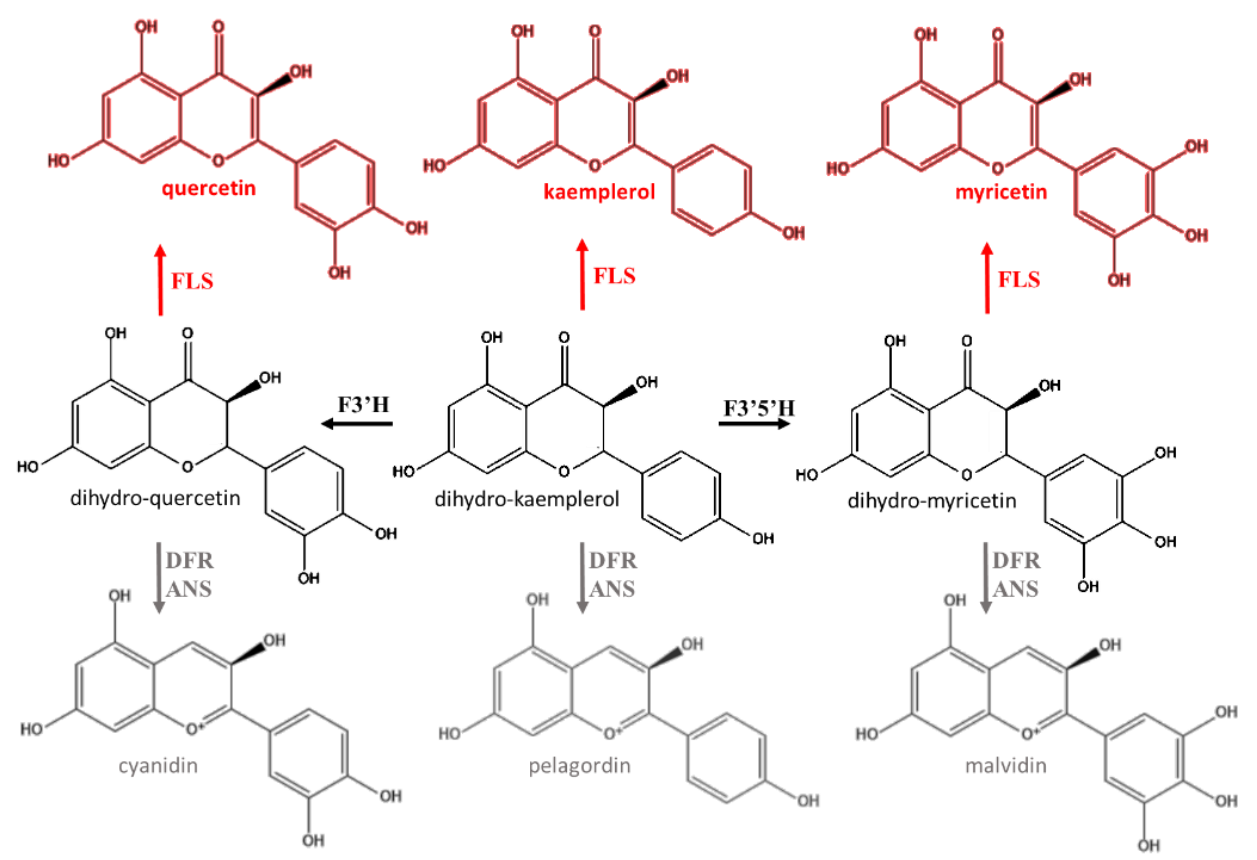

Figure 3. Alternative biochemical pathway to anthocyanin synthesis. FLS: flavonoid synthase; F3' $\mathrm{H}$ : flavonoid $3^{\prime}$-hydroxylase; F3' $5^{\prime} \mathrm{H}$ : flavonoid $3^{\prime}, 5^{\prime}$-hydroxylase; DFR: dihydroflavonol reductase; ANS: anthocyanidin synthase (ANS).

For these reasons, recently, anthocyanin role in plants was questioned. To date, it is well-known that these molecules are involved in several defensive processes, including the screen role against UV-B [45-49] and plant protection against high light intensities [46,49,50]. However, light stresses are not the only abiotic stress in which anthocyanins seem to play a key role. Indeed, thanks to their high antioxidant capacity, these flavonoids are involved in all those responses that contrast oxidative stress induced by heat conditions [51,52] and water and nutrient deficit $[51,53,54]$. Moreover, anthocyanins are also involved in response to biotic stresses, such as mechanical damage due to herbivore attack [55-57], insect infestation or fungal infection [58-60]. Table 1 reports the main abiotic and biotic stress conditions in which variations of the total content of anthocyanins were observed. 
Table 1. Documented plant responses to abiotic and biotic stresses that involves anthocyanins.

\begin{tabular}{|c|c|c|c|}
\hline \multicolumn{2}{|c|}{ Condition } & Specie & References \\
\hline \multirow{4}{*}{ Abiotic Stress } & Heat Stress & $\begin{array}{c}\text { Ipomoea batatas } \\
\text { Daucus carota } \\
\text { Rosa hybrida } \\
\text { Solanum melongena } \\
\text { Saccharum officinarum } \\
\text { Camellia sinensis } \\
\text { Sorghum vulgare } \\
\text { Vitis vinifera } \\
\text { Oryza glaberrima } \\
\text { Actinidia deliciosa } \\
\text { Arabidopsis thaliana } \\
\text { Quercus suber }\end{array}$ & $\begin{array}{c}{[43,61,62]} \\
{[63]} \\
{[64]} \\
{[65-68]} \\
{[69,70]} \\
{[71]} \\
{[72]} \\
{[73]} \\
{[74]} \\
{[75]} \\
{[76]} \\
{[77]}\end{array}$ \\
\hline & Light Stress & $\begin{array}{l}\text { Solanum melongena } \\
\text { Phalaenopsis aphrodite } \\
\text { Silene littorea } \\
\text { Arabidopsis thaliana } \\
\text { Chrysanthemum } \\
\text { morifolium } \\
\text { Begonia semperflorens } \\
\text { Brassica campestris } \\
\text { Perilla frutescens } \\
\text { Lonicera japonica } \\
\text { Actinidia deliciosa } \\
\text { Malus domestica }\end{array}$ & $\begin{array}{c}{[78-80]} \\
{[81]} \\
{[45]} \\
{[47,82-85]} \\
{[86]} \\
{[87]} \\
{[88]} \\
{[89,90]} \\
{[91]} \\
{[75]} \\
{[50,92]}\end{array}$ \\
\hline & Water Stress & $\begin{array}{l}\text { Camellia sinensis } \\
\text { Vitis vinifera } \\
\text { Hibiscus sabdariffa } \\
\text { Malus domestica } \\
\text { Fragaria ananassa } \\
\text { Ocimum basilicum } \\
\text { Sorghum vulgare } \\
\text { Oryza sativa } \\
\text { Punica granatum }\end{array}$ & $\begin{array}{c}{[93]} \\
{[51,94]} \\
{[95]} \\
{[96]} \\
{[97]} \\
{[54]} \\
{[98]} \\
{[99]} \\
{[53]}\end{array}$ \\
\hline & Salt Stress & $\begin{array}{l}\text { Arabidopsis thaliana } \\
\text { Nicotiana tabaccum } \\
\text { Hibiscus rosasinensis } \\
\text { Fragaria chiloensis } \\
\text { Oryza sativa } \\
\text { Solanum tuberosum }\end{array}$ & $\begin{array}{c}{[100-102]} \\
{[103]} \\
{[104]} \\
{[105]} \\
{[106]} \\
{[107]}\end{array}$ \\
\hline \multirow[t]{2}{*}{ Biotic Stress } & Insect Attack & $\begin{array}{l}\text { Arabidopsis thaliana } \\
\text { Gossypium arboreum } \\
\text { Solanum tuberosum } \\
\text { Sorghum halepense } \\
\text { Fragaria ananassa } \\
\text { Vaccinium myrtillus }\end{array}$ & $\begin{array}{c}55-57,108] \\
{[109]} \\
{[110]} \\
{[111]} \\
{[112]} \\
{[113]}\end{array}$ \\
\hline & Fungi Attack & $\begin{array}{c}\text { Arabidopsis thaliana } \\
\text { Oryza sativa } \\
\text { Fragaria ananassa }\end{array}$ & $\begin{array}{c}60,114,115] \\
{[99,106]} \\
{[59,116,117]}\end{array}$ \\
\hline
\end{tabular}

Beyond the involvement of anthocyanins to contrast the oxidative stress conditions related to abiotic and biotic menaces, anthocyanins seem to be also able to contribute to the physiological processes during non-stress conditions, such as the elevation of leaf temperature [91,118]; transport of nutrients and monosaccharides [119-121]; and regulation of osmotic balance [51,105]. Table 2 reports the main plant physiological pathways in which anthocyanins are involved. 
Table 2. Documented plant physiological processes in which anthocyanins are involved.

\begin{tabular}{ccc}
\hline Plant Physiological Role & Specie & References \\
\hline Elevation of Leaf Temperature & Several species & {$[121-126]$} \\
& Lactuca sativa & {$[127]$} \\
& Arabidopsis thaliana & {$[128,129]$} \\
Senescence & Galax urceolata & {$[130]$} \\
\hline & Several species & {$[131-134]$} \\
& Populus euramericana & {$[135]$} \\
& Arabidopsis thaliana & {$[136,137]$} \\
Transportation of Monosaccharides & Brassica oleracea & {$[138]$} \\
& Actinidia deliciosa & {$[139]$} \\
& Torenia fournieri & {$[140]$} \\
\hline Regulation of Osmotic Balance & Several Species & {$[119-121]$} \\
& Zea mays & {$[141,142]$} \\
& Vitis vinifera & {$[143-145]$} \\
\hline Enhancing of Light Absorption & Several species & {$[125,146,147]$} \\
& Xerophyta viscosa & {$[148]$} \\
& Vitis vinifera & {$[149-151]$} \\
& Fragaria ananassa & {$[152]$} \\
& Populus deltoides & {$[153]$} \\
& Arabidopsis thaliana & {$[76,129]$} \\
& Craterostigma wilmsii & {$[148]$} \\
\hline & Several Species & {$[123,154-160]$} \\
& Theobroma cacao & {$[121]$} \\
& Mangifera indica & {$[121]$} \\
\hline & Several Species & {$[126,155,161-163]$} \\
& Theobroma cacao & {$[121]$} \\
& Zea mays & {$[121]$} \\
\hline
\end{tabular}

\subsection{Distribution in Edible Sources and Contribution in Human Diet}

Fruits and vegetables are the only edible sources from which it is possible assuming anthocyanin compounds $[26,165]$. Although among the fruits the anthocyanin content is very variable, generally the level of anthocyanins in fruits is much higher than in vegetables [166]. The lowest anthocyanin content per $100 \mathrm{~g}$ of fresh weight was recorded for grapefruit [167,168], date [169], and fig [170], meanwhile some berries, such as cranberry [19], chokeberry [171], huckleberry [172], blueberry [173], raspberry [174,175], and bilberry $[176,177]$ shows the highest one. Concerning vegetables, the most reach in anthocyanidins and anthocyanins are red cabbage [178-180], purple cabbage [181], and purple potato $[61,182]$. However, total anthocyanin content in fruits and vegetables considerably varies among the different genera and cultivars, and it is strongly affected by different light, temperature, and agronomic factors [183]. Figure 4 shows the cluster distribution of anthocyanins in plant kingdom according to the anthocyanin content reported in PhenolExplorer Online Database [184-186]. For this analysis, Euclidean distances were calculated by using the average linkage method. 


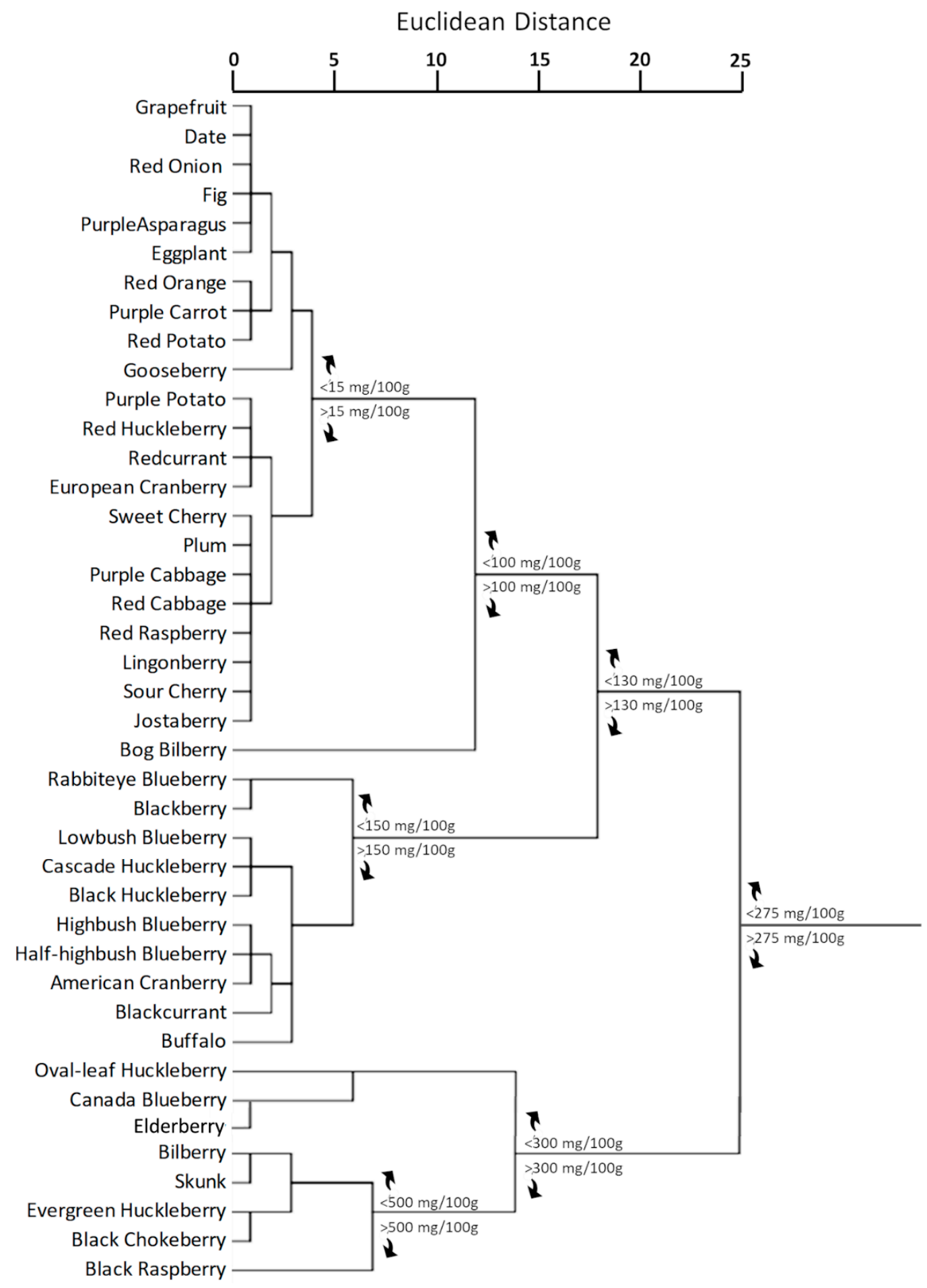

Figure 4. Cluster distribution of anthocyanins in plant kingdom based on the total anthocyanin content according to Phenol-Explorer Database [184-186]. Euclidean distances were calculated with average linkage method. Statistical analysis and graphical representation were made using SPSS v. 24 software. The cluster was generated by using SPSS ver.24 statistical software.

In the recent years, some flowers were proposed as alternative edible sources of phytochemicals. In order to be included in human diet, flowers have to be non-toxic and innocuous $[187,188]$. Indeed, flowers may contain toxic substances, including hemaglutinnins, oxalic acid, cyanogenic glycosides, or alkaloids and cause severe damage to the consumers [187]. However, many flowers can be considered safe, and therefore can be consumed as food. Although flowers are little known as edible sources, they have been 
used for over 500 years in Europe and China as herbal medicine [189]. Actually, they are mainly used for enhancing the aesthetic value of foods, as evidenced by the increasing number of edible flower cookbooks, culinary magazine articles, and dedicated television segments $[190,191]$. Despite edible flowers are still considered a niche product, they are gaining attention due to their exotic aroma and textures, delicate flavor, attractive color and phytochemical composition [192]. In particular, edible flowers are a potential source of several bioactive compounds, including anthocyanins [191-193]. Among them, begonia (Begonia tuberhybride), tagete (Tagetes patula), mini rose (Rosa chinensis), mini daisy (Bellis annua), litoria (Clitoria ternatea), cosmos (Cosmos sulphureus), and cravine (Dianthus chinensis) are the most known and commercialized [192].

Apart from their origins and physiological roles in plants, anthocyanidins and anthocyanins seem to play important roles in human health and well-being $[19,27,177]$. Indeed, their intaking through the consumption of foods rich in these flavonoid compounds seems to be linked to an improvement of the redox balance thanks to their high scavenging and reducing activities $[19,183,194]$. On the other hand, interesting properties, such as antitumor, antiatherogenic, antiviral, and anti-inflammatory effects, decrease of capillary permeability and fragility, inhibition of platelet aggregation and immune stimulation were reported [195]. The positive effects ascribed to the consumption of fruits and vegetables rich in anthocyanidins and anthocyanins are not limited to the gastro-intestinal tract. Indeed, anthocyanins resisting to gastric digestion may be absorbed in the stomach via bilitranslocase-mediated mechanism [196-199], or in the intestine through a mechanism involving the sodium-glucose co-transporter as suggested for other flavonoids [197-201].

\section{Plant Biostimulants}

Biostimulants are products used in agriculture aimed to promote plant growth without being nutrients, soil improvers, or pesticides $[1,9,13,202,203]$. In particular, biostimulants are distinguished from agrochemicals because they only influence the vigor of plants and have no direct action against pests or diseases. Rather, they uniquely facilitate the uptake of existing and applied nutrients [204], resistance to abiotic stress such as salinity $[6,11,100,205,206]$, temperature $[2,13,207-211]$, or drought [208,212-216], following in an improvement of the final production also in adverse environmental conditions [1].

\subsection{Bibliometric Analysis}

According to PubMed database, 1680 scientific papers related to biostimulant research were published from 1958, indicating an increasing interest for this sustainable agronomic practice. However, despite products working as biostimulants are used as alternative agronomic practice since more than 20 years, only recently biostimulants are deeply under investigation. Indeed, more than $50 \%$ of the 1680 papers (856) concerning biostimulants have been published in the last 5 years. Moreover, the title, abstract, and the keywords of the papers published in the last 5 years were used for bibliometric analysis aimed to find the co-occurrence of terms using VOSviewer 1.6.15 [217,218]. In order to avoid redundancies, only the words that were repeated at least five times in the text were used for this analysis; typographical errors were removed and similar terms were standardized to a single form. Consequently, 50 terms were selected, and clustered according to the association strength (from -1 to +1 ). Finally, a visual cluster analysis (Figure 5, Panel A) was generated, where 6 clusters and 585 links were identified and integrated into a network pathway.

Focusing on the term "plant biostimulant" (Figure 5, Panel B) we found a strong correlation with the different typologies of formulations currently present on the market. Although, biostimulants are formulated with a great variety of ingredients, they are generally classified into algal-based, protein hydrolysate, aminoacid-based, humic acid, fulvic acid, food and industrial waste-based, and microbial inoculant [219]. 


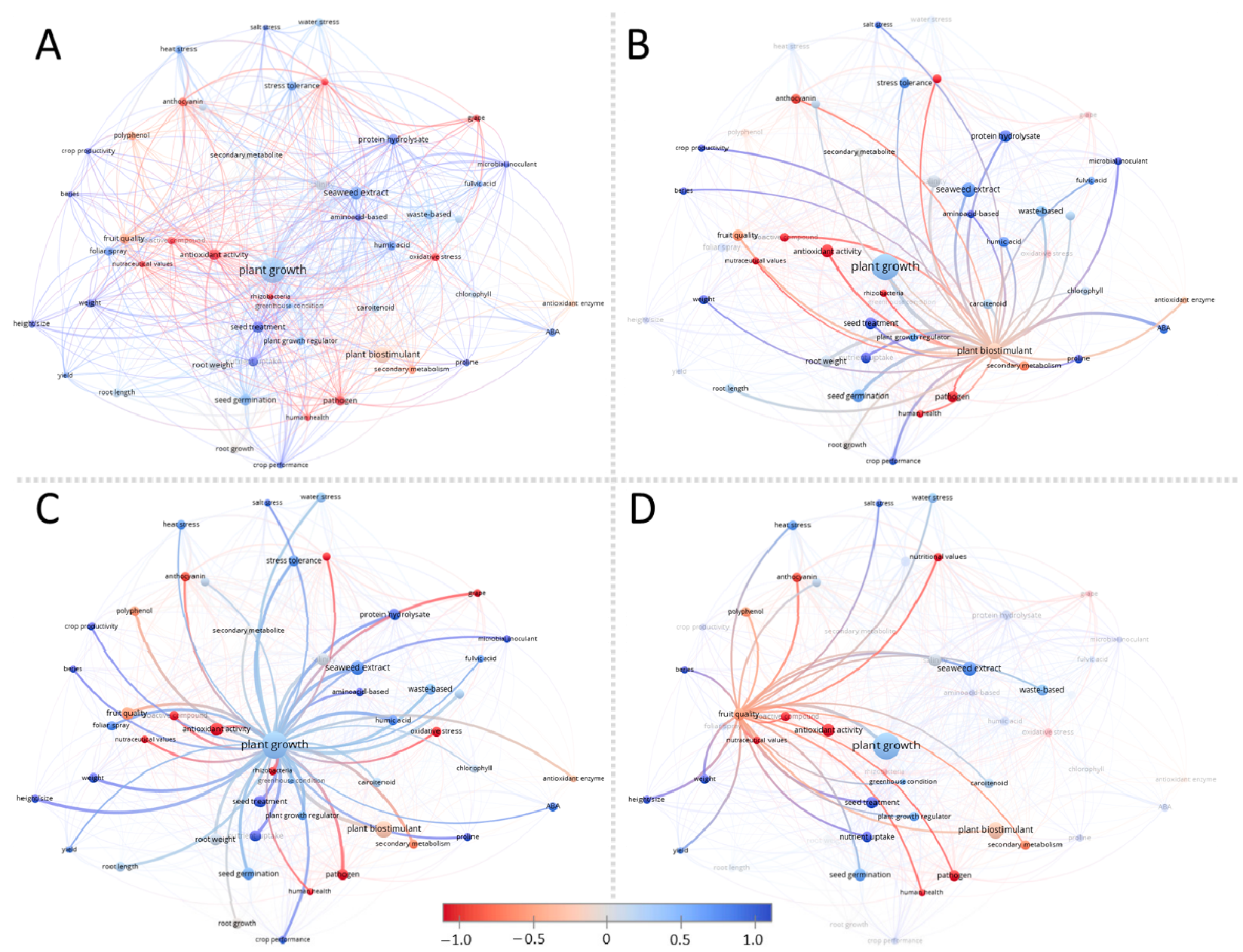

Figure 5. Visual cluster analysis generated using papers published during the last 5 years and related to biostimulant products. The plot was generated by using VOSviewer software (ver. 1.6.15) [217,218]. Panel (A) reports the general plot; Panel (B) highlights the connections between the terms "Plant Biostimulant" and other terms; panel (C) highlights the connections between the terms "Plant Growth" and other terms; panel (D) highlights the connections between the terms "Fruit Quality" and other terms. For each panel, the bubble map visualizes the 50 most frequent terms that appeared in the papers published in the last 5 years $(n=856)$. Bubble size indicates the frequency of occurrence of the words; the color indicates the association strength (from -1 to +1 ); the lines between bubbles represent the linkage among terms.

Meanwhile "plant growth" were the words most used in the 865 articles (Figure 5, panel C), "fruit quality" and "human health" resulted to be the least commons. This result should not be surprising, since researches always focused on the potential effects derived from the application of the biostimulant products on agronomical ("plant weight," "plant height," "crop productivity," "crop performance") and plant physiological ("chlorophyll," "proline," "abscisic acid," "secondary metabolism") parameters. In particular, these parameters were almost exclusively investigated in stress conditions, such as "heat stress," "water deficit," and "salt stress."

Finally, our analysis revealed that only few researches dealt with the quality of fruits produced by plants treated with biostimulant. This is also confirmed by the publication of only 20 papers in the last 5 years regarding the evaluation of the fruit quality after the treatment with biostimulants. In particular, as it is showed in Figure 5, Panel D, only some attributes related to fruit quality were deeply investigated, such as those pomological ("weight" and "size") and those related to production ("yield") parameters. On the other hand, the potential effects of the biostimulant application on fruit quality, in term of both nutritional and nutraceutical attributes, and on "human health" were poorly studied [1]. In the following sections, we report what has currently been published regarding the effect 
of biostimulants on fruit quality, with special attention to anthocyanin and anthocyanidin content.

\subsection{Plant Biostimulant Treatment Affecting the Quality of Edible Fruits and Vegetables}

Among the different parameters evaluated for fruit quality, color is one of the major factors in creating a positive image of the fruit for the consumers, and consequently it has a great effect on sales [1]. As previously mentioned, the red-violet color in several fruits is due to the presence of anthocyanins and anthocyanidins, and their estimation is then an aspect belonging the fruit quality [220,221]. Here, we report a forest plot in which randomized-controlled studies comparing the effect derived from the application of biostimulants on total anthocyanin content against control group (water only treated) are displayed (Figure 6). Inclusion criteria were: (i) Studies had to report a quantitative analysis of anthocyanin content; (ii) among the experimental conditions, unstressed plants had to be used as controls; (iii) the number of biological replicates evaluated during the trials had to be clearly expressed; (iv) no restrictions regarding publication dates were imposed; (v) the studies were eligible exclusively if they were published in English; (vi) studies had to be published in peer reviewed scientific journals. Outcome measures included both the evaluation of the total anthocyanin content via spectrophotometric and chromatographic methodologies. Consequently, data from 12 publications were identified and included in the meta-analysis (Figure 6).

\begin{tabular}{|c|c|c|c|c|c|c|c|c|c|c|}
\hline \multirow[b]{2}{*}{ Study or Subgroup } & \multicolumn{3}{|c|}{ Experimental } & \multicolumn{3}{|c|}{ Control } & \multicolumn{2}{|r|}{ Std. Mean Difference } & \multirow{2}{*}{\multicolumn{2}{|c|}{$\begin{array}{l}\text { Std. Mean Difference } \\
\text { IV, Random, } 95 \% \mathrm{Cl}\end{array}$}} \\
\hline & Mean & SD & Total & Mean & SD & Total & Weight & N, Random, 95\% Cl & & \\
\hline Pohl, 2019 & 6.67 & 1.16 & 8 & 1.98 & 0.98 & 8 & $5.9 \%$ & $4.13[2.21,6.05]$ & & \\
\hline Soppelsa, 2020 & 1.71 & 0.21 & 9 & 0.82 & 0.23 & 9 & $6.6 \%$ & $3.85[2.15,5.55]$ & & \\
\hline Soppelsa, 2018 & 107.94 & 8.63 & 20 & 58.07 & 8.52 & 20 & $7.3 \%$ & $5.70[4.25,7.15]$ & & \\
\hline Correia, 2020b & 1.37 & 0.07 & 15 & 1.03 & 0.08 & 15 & $7.5 \%$ & $4.40[3.01,5.79]$ & & \\
\hline Roussos, 2009 & 34.57 & 1.03 & 11 & 31.11 & 1.12 & 11 & $7.7 \%$ & $3.09[1.78,4.40]$ & & \\
\hline Gonçalves, 2020 & 50.47 & 2.93 & 9 & 42.63 & 7.09 & 9 & $8.5 \%$ & $1.38[0.32,2.43]$ & & \\
\hline Soppelsa, 2020b & 0.64 & 0.06 & 9 & 0.35 & 0.29 & 9 & $8.5 \%$ & $1.32[0.27,2.36]$ & & \\
\hline Kok, 2018 & 184 & 87.96 & 15 & 56.91 & 5.88 & 15 & $9.0 \%$ & $1.98[1.09,2.88]$ & & \\
\hline Correia, 2020 & 2.32 & 0.17 & 15 & 2.11 & 0.25 & 15 & $9.3 \%$ & $0.96[0.19,1.72]$ & & $\rightarrow$ \\
\hline Lombardi, 2020 & 10.72 & 2.23 & 30 & 8.09 & 1.36 & 30 & $9.8 \%$ & $1.41[0.84,1.97]$ & & $\rightarrow$ \\
\hline Pohl, 2019b & 3.22 & 1.59 & 40 & 1.91 & 0.44 & 40 & $10.0 \%$ & $1.11[0.64,1.58]$ & & $\rightarrow$ \\
\hline Porrado, 2007 & 2.65 & 1.08 & 40 & 2.01 & 1.13 & 40 & $10.0 \%$ & $0.57[0.13,1.02]$ & & $\rightarrow$ \\
\hline Total $(95 \% \mathrm{Cl})$ & & & 221 & & & 221 & $100.0 \%$ & $2.28[1.57,3.00]$ & & \\
\hline $\begin{array}{l}\text { Heterogeneity: Tau² } \\
\text { Test for overall effect }\end{array}$ & $\begin{array}{l}.27 ; \mathrm{Chi} \\
=6.26\end{array}$ & $\begin{array}{l}z=91.0 \\
P<0.00\end{array}$ & $\begin{array}{l}\text { 5, df }= \\
0001)\end{array}$ & $11(P$ & 0.00 & 01); $\left.\right|^{2}=$ & $88 \%$ & & $\begin{array}{cc}1 & 1 \\
-4 & -2 \\
\text { Favours [experimental] }\end{array}$ & $\begin{array}{ccc} & 2 & 4 \\
\text { Favours [contro }\end{array}$ \\
\hline
\end{tabular}

Figure 6. Forest plot for the effects of biostimulant application on anthocyanin content of the analyzed studies [15,222-230], plotted according to the standard mean difference. The weight of each study is represented by the size of the green box. The forest plot displays a horizontal line that indicates the lower and upper limits of the 95\% confidence interval (CI) of the effect reported for each study. The vertical line represents the no-effect, and if it crosses the horizontal lines it indicates the non-significance of the data reported in the respective study. The black diamond at the bottom represents the average effect size. Heterogeneity was assessed using $I^{2}$ statistical test, that represents the amount of total variation that could be attributed to heterogeneity. The figure was generated by Review Manager Software, ver. 5.4.1.

Analyzing the forest plot, there was evidence of heterogeneity $\left(I^{2}=88 \%, p>0.0001\right)$ but no evidence of publication bias was detected after the examination of funnel plot (Figure 7). This is the first study to systematically review the effect derived from the biostimulant application and the increasing of anthocyanin content in fruits produced from biostimulant-treated plants. Our meta-analysis showed strong evidence of association between biostimulants and the increasing of anthocyanin compounds. These findings are in line with previous works that have found a relationship between the biostimulant application and the general improvement of polyphenolic compounds in fruits harvested from plants treated with different biostimulants [231,232], supporting the notion that these products may promote the fruit quality affecting the content of these pigments. In the 
following sections, we analyze in detail the works in which quantitative and qualitative variations of anthocyanin compounds have been recorded.

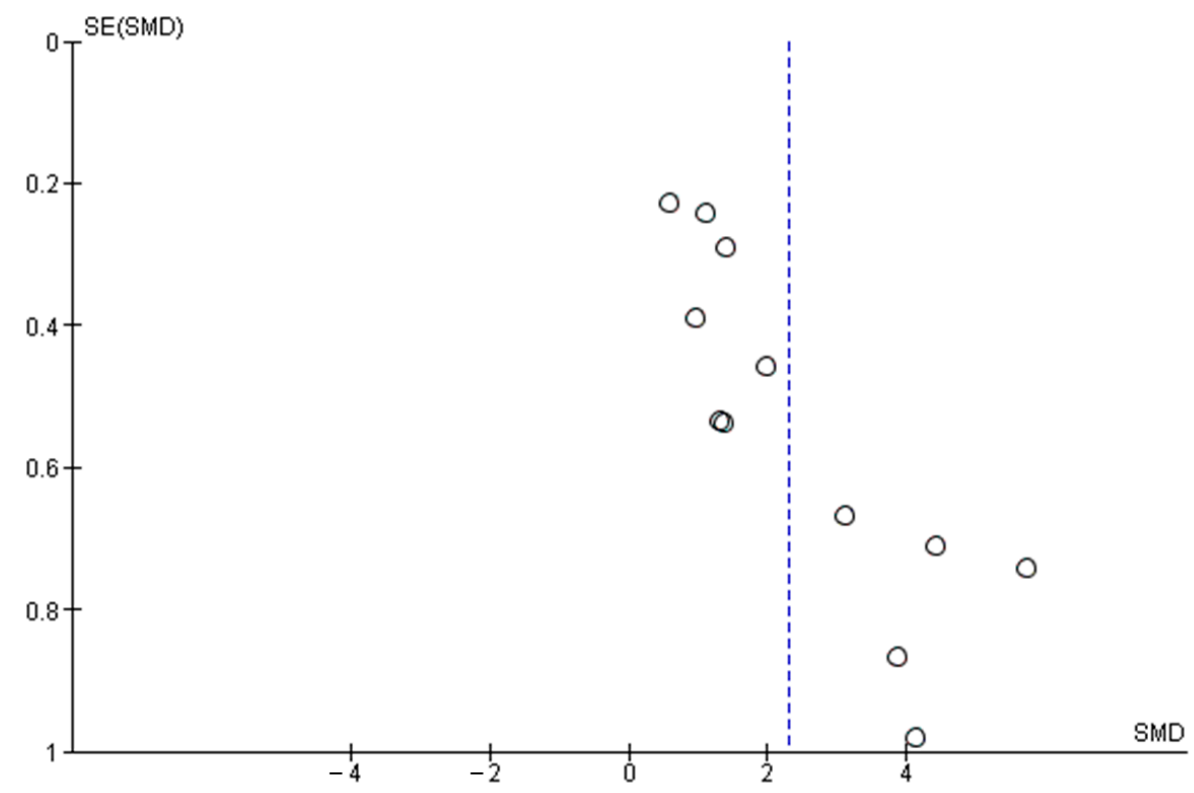

Figure 7. Funnel plot showing symmetrical distribution of studies indicating absence of publication bias in studies measuring the anthocyanin content in plants treated with the biostimulants. The figure was generated by Review Manager Software, ver. 5.4.1.

\subsubsection{Apple (Malus domestica)}

Apples are the most common fruits consumed all over the world, and they are a very rich source of antioxidant bioactive compounds, including polyphenols. The coloration of red apple skin derives from the presence of anthocyanins in the fruit epicarp, especially glycosylated Cy, such as cyanidin-3-O-glycosides and cyanidin-3-O-galactosides [233].

In a recent work, Soppelsa et al. evaluated the effects derived by the application of ten different typologies of biostimulants on apple quality [223]. They conducted the experiments during two consecutive seasons using biostimulants based on humic acids (HA), seaweed extracts (SWE), protein hydrolysates $(\mathrm{PH})$, amino acids (AAB), vitamins (VTB), chitosan (CHTB), or containing silicon (SLB). The parameters related to fruit quality included pomological, physiochemical, nutritional, and nutraceutical attributes. At the end of the experimentation, they showed how the application of the biostimulants did not affect the tree productivity as well as physiochemical parameters of the fruits, such as flesh firmness (FF), total soluble solids (TSS), and total acidity (TA). On the other hand, one of the major effects of the biostimulant application was the significant change in skin apple coloration. However, the observed effect was detected only in apples treated with SWE, PH, and VTB. Their results were also supported by the evaluation of the total anthocyanidin content (TAC), showing that apples treated with these biostimulants presented an anthocyanin concentration double than the respective untreated fruits. Consequently, when authors evaluated the total polyphenol content (TPC) and antioxidant activity via ABTS assay, they found higher values for the apples treated with the mentioned biostimulants. Authors, according to previously published data [234], hypothesized that the boosted final red coloration might be linked to the modulation of plant endogenous growth regulators (such as cytochins and abscisic acid). These events led to an enhancement of anthocyanin biosynthesis and accumulation in the skin during ripening.

In a more recent work the effect derived from the application of $\mathrm{CaCl}_{2}$ alone or in combination with SWE or with a commercial biostimulant formulation enriched in silicon and zinc was evaluated [224]. Also in this case, SWE application did not affect the final yield, meanwhile the treatment was able to affect the coloration of the fruit skin enhancing the anthocyanin production. In addition, an effect on the accumulation of $\mathrm{Ca}, \mathrm{Zn}$, and $\mathrm{Mn}$ 
in the apple skin was observed after the application of both typologies of biostimulants. In addition, the authors suggested that the accumulation of these minerals in the skin, along with the increase of phenolic compounds during fruit ripening and storage, may represent the principal explanations of the reduced fruit susceptibility to post-harvest disorders.

\subsubsection{Eggplant (Solanum melongena)}

Among the vegetables, eggplants are one of the edible sources having very high amount of anthocyanins stored mainly in the skin. In particular, the skin showed to be rich in the rutinoside forms of Mv, Cy, and Pn [235]. However, the effect of biostimulant products on eggplants is actually less studied.

Pohl et al. studied the effects resulting from the application of SWE biostimulant derived from Ascophyllum nodosum [222] on six different eggplant cultivars (Cristal, Epic, Flavine, Gascona, and Onyx, WA 6020). In this work, they showed that all the plants treated with SWE set higher number of fruits of smaller diameter, resulting in a significant increment of total and marketable yield. Concerning the nutraceutical properties, the authors highlighted how the effect could be significantly different among cultivars. In particular, they reported that some cultivars (Cristal, Epic and WA 6020) recorded a more significant increase of TAC after the application of the biostimulant.

Sabatino et al. who inoculated Rhizophagus irregularis mycorrhiza on eggplant rootstocks, showed how FF was positively affected, in addition to several nutritional values, such as P, Fe, and protein content. From a nutraceutical point of view, also higher values of ascorbic acid, TPC, TAC, chlorogenic acid and glycoalkaloids were observed [236].

\subsubsection{Grape (Vitis vinifera)}

Due to the economic impact of grape and its related products, the effect of biostimulant application on Vitis vinifera is certainly one of the most studied. In general, biostimulants were employed with the aim to promote plant growth and fruit quality, and in particular several of the published manuscripts investigated how to improve the color of skin grape because it is not only directly linked to fruit maturity, but also to the good preparation of food secondary processed foods, including wines [237].

Tommaso Frioni et al. studied the effects derived from the spray application of a SWE biostimulant containing Ascophyllum nodosum extracts on three different grape cultivars (Sangiovese grown under Mediterranean conditions, Pinot Noir and Cabernet Franc within a cool-climate viticulture region) [238]. The product was sprayed five times during the season at the doses described in the product label. The authors found that SWE was not able to affect leaf gas exchanges, fruit yield, berry cluster or fruit size, but positively affected the phenolic content. In particular, the authors found that anthocyanins were strongly accumulated in the skin of the fruits. Overall, they hypothesized that the biostimulant might boost anthocyanins and other polyphenols close to veraison and then later in the season, maintaining active the accumulation before harvest. This hypothesis was supported by the fact that SWE-triggering anthocyanin biosynthesis in grape skins anticipated veraison. Finally, they also described an effect dependent on the genotype, due to the recording of higher values in Sangiovese and Pinot Noir cultivars than in Cabernet Franc.

Similar results were also obtained in a more recent study, in which the effect observed after the foliar application of a similar biostimulant was evaluated on both physiological and biochemical parameters of Vitis vinifera (cv. Sangiovese) [239]. In this work, the authors stated the SWE-based biostimulant was able to affect the eco-physiological parameters and secondary metabolic pathways, resulting in improved grape quality. In particular, the applications of $A$. nodosum extract had significant effects on phenylpropanoid biosynthesis, both in berry skins and in leaves, influencing anthocyanin partitioning and lowering the biosynthesis of methoxylated compounds. However, in disagreement with Frioni, Palliotti et al. also observed an improvement of the leaf gas exchanges, maximum photosystem II efficiency, and grape maturity. 
A very recent work studied the effect derived from the application of a natural biostimulant in the accumulation of anthocyanins in "Red Globe" grapes, by investigating the potential mechanism of action through the study of the changes in gene expression and activities of proteins involved in flavonoid pathways [221]. In particular, these authors found that after the treatment with the biostimulant all genes involved in the anthocyanin biosynthesis were up-regulated and the activities of the key enzymes related to this pathway, including PAL, CHI, UFGT, and DFR, increased.

\subsubsection{Cherry (Prunus avium)}

Sweet cherry has a relevant economical value due to its commercial characteristics, nutritional value, and beneficial health effects [240]. Unfortunately, the quality of cherries is severely compromised by climatic conditions, resulting in a significant economic loss. Despite this, only limited studies have attempted to find solutions to the problem using sustainable agronomic techniques. Berta Gonçalves et al. studied the effect of salicylic acid, glycine-betaine complex, and SWE as biostimulants applied during pre-harvest period by foliar spray [225]. The effects were evaluated on the "Staccato" cultivar, and the authors found that all the treatments positively affected size, soluble solid content, $\mathrm{pH}$, color, antioxidant activity, polyphenol, and vitamin C content. Among the tested biostimulants, glycine-betaine and SWE products showed the best results, in term of physiochemical, nutritional, and nutraceutical parameters. In particular, authors found that cherries treated with this biostimulant showed a higher content of neochlorogenic, p-coumaric, chlorogenic acids, cyanidin-3-O-rutinoside and cyanidin-3-O-glucoside, rutin, luteolin, and vitamin C. These results were in correlation with a higher antioxidant capacity.

Sofia Correia et al. treated Skeena sweet cherry trees by repeated foliar spray applications of a biostimulant based on $\mathrm{Ca}$, gibberellic acid, abscisic acid, salicylic acid, glycine betaine, and SWE [15]. They measured the physiological and biochemical performance for two consecutive years (2015-2016) and demonstrated that the biostimulant application increased the physiological performance and water status of the trees. Among the different formulations, the spray application of SWE was shown to be the best for increasing yield and reducing cherry cracking as well as improving photosynthetic performance and leaf metabolite content. Moreover, also maturity index and anthocyanin content in cherries were strongly increased after the application of ABA-based biostimulant and SWE.

\subsubsection{Strawberry (Fragaria ananassa)}

For centuries, strawberries have been consumed mainly because of their sweet taste, but the potential of this fruit is mainly related to its phytochemical composition. Indeed, strawberries are a good source of vitamin C, anthocyanins, proanthocyanidins, and other antioxidants, and its consumption is correlated to cardiovascular protection and antiinflammatory effects [241]. The results derived from the application of biostimulant aimed to preserve, or increase, the nutritional and nutraceutical content of these fruits, were largely investigated.

For example, Guido Lingua et al. in 2013 studied the effect of arbuscular mycorrhiza colonization on the amount of anthocyanins, showing how the symbiosis could induce an increase of TAC [59]. Moreover, the authors investigated the qualitative anthocyanin profile via HPLC-MS/MS and discovered that $\mathrm{Cy}$ and Pg were the most varying anthocyanins. In 2020, Nadia Lombardi et al. studied the effects of treatments with three selected Trichoderma strains (T22, TH1, and GV41) in strawberry plants, by measuring the productivity, primary and secondary metabolites, and proteome of the formed fruits [227]. They reported that the application of the biostimulant positively affected plant growth, increased fruit yield, and favoured the selective accumulation of anthocyanins in the skin of red ripened fruits. By performing HPLC analysis, they found that not all anthocyanins were equally affected by the biostimulant application. In particular, only the glucoside and rutinoside forms of Cy or Pg were affected by the treatment. With the aim to understand the mechanism that led to a higher anthocyanin accumulation in the fruits, they performed proteomic 
analysis and demonstrated that the microbial inoculants highly affected the profile of proteins associated with responses to stress/external stimuli, nutrient uptake, protein metabolism, carbon/energy metabolism, and secondary metabolism. Moreover, bioinformatic analysis revealed a concomitant modulation of different plant physiological processes following the microbial inoculation. To this purpose, they found that in treated plants there was an increased level of PAL, CHI, and other enzymes involved in anthocyanin biosynthesis, meanwhile proteins catalyzing the transformation of secondary metabolites into lignin derivatives, such as elicitor-activated genes, and isoflavone reductases were down represented.

\section{Conclusions}

The application of plant biostimulants as agriculture practice represents a sustainable way to reduce fertilizers and other chemicals, also reducing the environmental contamination. This aspect increased the attention not only of the farmers but also of consumers, who are more confident in sustainable foods because perceived safer and healthier. As reported in this review, plant biostimulants are shown to be able to increase fruit quality parameters in plant grown both in controlled and adverse conditions. However, compared with the high number of published reports, few scientific papers were focused on fruit quality in term of nutraceutical aspects, and in particular on a punctual class of bioactive compounds, such as anthocyanins. Moreover, most part of the published papers simply reports the effects of biostimulant applications on plants, but few have investigated their potential mechanisms of action. Consequently, it is important to highlight the urgent need for further studies that should be focused on the biostimulant chemical composition and on the investigation of the biochemical and molecular pathways involved in their displayed actions.

Author Contributions: Conceptualization, G.M., C.G., and C.M.B.; investigation, G.M., G.S., A.E., C.G., and C.M.B.; data curation, G.M., C.G., and C.M.B.; writing-original draft preparation, G.M., A.E., C.G., and C.M.B.; writing-review and editing, G.M., C.G., G.S., A.E., and C.M.B.; visualization, G.M.; supervision, G.M., C.G., A.E., and C.M.B. All authors have read and agreed to the published version of the manuscript.

Funding: This research received no external funding.

Data Availability Statement: No new data were created or analyzed in this study. Data sharing is not applicable to this article.

Conflicts of Interest: The authors declare no conflict of interest.

\section{References}

1. Mannino, G.; Campobenedetto, C.; Vigliante, I.; Contartese, V.; Gentile, C.; Bertea, C.M. The application of a plant biostimulant based on seaweed and yeast extract improved tomato fruit development and quality. Biomolecules 2020, 10, 1662. [CrossRef]

2. Campobenedetto, C.; Grange, E.; Mannino, G.; Van Arkel, J.; Beekwilder, J.; Karlova, R.; Garabello, C.; Contartese, V.; Bertea, C.M. A biostimulant seed treatment improved heat stress tolerance during cucumber seed germination by acting on the antioxidant system and glyoxylate cycle. Front. Plant Sci. 2020, 11, 836. [CrossRef]

3. Di Mola, I.; Ottaiano, L.; Cozzolino, E.; Senatore, M.; Giordano, M.; El-Nakhel, C.; Sacco, A.; Rouphael, Y.; Colla, G.; Mori, M. Plant-based biostimulants influence the agronomical, physiological, and qualitative responses of baby rocket leaves under diverse nitrogen conditions. Plants 2019, 8, 522. [CrossRef] [PubMed]

4. Povero, G.; Mejia, J.F.; Di Tommaso, D.; Piaggesi, A.; Warrior, P. A systematic approach to discover and characterize natural plant biostimulants. Front. Plant Sci. 2016, 7, 435. [CrossRef] [PubMed]

5. Petropoulos, S.A.; Fernandes, Â.; Plexida, S.; Chrysargyris, A.; Tzortzakis, N.; Barreira, J.C.M.; Barros, L.; Ferreira, I.C.F.R. Biostimulants application alleviates water stress effects on yield and chemical composition of greenhouse green bean (phaseolus vulgaris L.). Agronomy 2020, 10, 181. [CrossRef]

6. Campobenedetto, C.; Mannino, G.; Beekwilder, J.; Contartese, V.; Karlova, R.; Bertea, C.M. The application of a biostimulant based on tannins affects root architecture and improves tolerance to salinity in tomato plants. Sci. Rep. 2021, 11, 354. [CrossRef]

7. Carillo, P.; Ciarmiello, L.F.; Woodrow, P.; Corrado, G.; Chiaiese, P.; Rouphael, Y. Enhancing sustainability by improving plant salt tolerance through macro- and micro-algal biostimulants. Biology 2020, 9, 253. [CrossRef] [PubMed] 
8. Abou Chehade, L.; Al Chami, Z.; De Pascali, S.A.; Cavoski, I.; Fanizzi, F.P. Biostimulants from food processing by-products: Agronomic, quality and metabolic impacts on organic tomato (Solanum lycopersicum L.). J. Sci. Food Agric. 2018, 98, $1426-1436$. [CrossRef]

9. El Boukhari, M.E.M.; Barakate, M.; Bouhia, Y.; Lyamlouli, K. Trends in seaweed extract based biostimulants: Manufacturing process and beneficial effect on soil-plant systems. Plants 2020, 9, 359. [CrossRef]

10. Pereira, C.; Dias, M.I.; Petropoulos, S.A.; Plexida, S.; Chrysargyris, A.; Tzortzakis, N.; Calhelha, R.C.; Ivanov, M.; Stojković, D.; Soković, M.; et al. The Effects of biostimulants, biofertilizers and water-stress on nutritional value and chemical composition of two spinach genotypes (Spinacia oleracea L.). Molecules 2019, 24, 4494. [CrossRef] [PubMed]

11. Hoffmann, J.; Berni, R.; Hausman, J.-F.; Guerriero, G. A Review on the beneficial role of silicon against salinity in non-accumulator crops: Tomato as a model. Biomolecules 2020, 10, 1284. [CrossRef]

12. Dal Cortivo, C.; Conselvan, G.B.; Carletti, P.; Barion, G.; Sella, L.; Vamerali, T. Biostimulant effects of seed-applied sedaxane fungicide: Morphological and physiological changes in maize seedlings. Front. Plant Sci. 2017, 8, 2072. [CrossRef] [PubMed]

13. Campobenedetto, C.; Mannino, G.; Agliassa, C.; Acquadro, A.; Contartese, V.; Garabello, C.; Bertea, C.M. Transcriptome analyses and antioxidant activity profiling reveal the role of a lignin-derived biostimulant seed treatment in enhancing heat stress tolerance in soybean. Plants 2020, 9, 1308. [CrossRef]

14. Pittarello, M.; Busato, J.G.; Carletti, P.; Zanetti, L.V.; da Silva, J.; Dobbss, L.B. Effects of different humic substances concentrations on root anatomy and Cd accumulation in seedlings of Avicennia germinans (black mangrove). Mar. Pollut. Bull. 2018, 130, 113-122. [CrossRef] [PubMed]

15. Correia, S.; Queirós, F.; Ferreira, H.; Morais, M.C.; Afonso, S.; Silva, A.P.; Gonçalves, B. Foliar application of calcium and growth regulators modulate sweet cherry (Prunus avium L.) tree performance. Plants 2020, 9, 410. [CrossRef]

16. Luziatelli, F.; Ficca, A.G.; Colla, G.; Baldassarre Švecová, E.; Ruzzi, M. Foliar Application of vegetal-derived bioactive compounds stimulates the growth of beneficial bacteria and enhances microbiome biodiversity in lettuce. Front. Plant Sci. 2019, 10, 60. [CrossRef]

17. Francesca, S.; Arena, C.; Hay Mele, B.; Schettini, C.; Ambrosino, P.; Barone, A.; Rigano, M.M. The Use of a plant-based biostimulant improves plant performances and fruit quality in tomato plants grown at elevated temperatures. Agronomy 2020, 10, 363. [CrossRef]

18. Bajpai, S.; Shukla, P.S.; Asiedu, S.; Pruski, K.; Prithiviraj, B. A biostimulant preparation of brown seaweed ascophyllum nodosum suppresses powdery mildew of strawberry. Plant Pathol. J. 2019, 35, 406-416. [CrossRef]

19. Mannino, G.; Di Stefano, V.; Lauria, A.; Pitonzo, R.; Gentile, C. Vaccinium macrocarpon (cranberry)-based dietary supplements: Variation in mass uniformity, proanthocyanidin dosage and anthocyanin profile demonstrates quality control standard needed. Nutrients 2020, 12, 992. [CrossRef]

20. Astrup, A. Healthy lifestyles in Europe: Prevention of obesity and type II diabetes by diet and physical activity. Pub. Health Nutr. 2001, 4, 499-515. [CrossRef]

21. Blüher, M. Obesity: Global epidemiology and pathogenesis. Nat. Rev. Endocrinol. 2019, 15, 288-298. [CrossRef]

22. Swallah, M.S.; Sun, H.; Affoh, R.; Fu, H.; Yu, H. Antioxidant potential overviews of secondary metabolites (polyphenols) in fruits. Int. J. Food Sci. 2020, 2020. [CrossRef] [PubMed]

23. Brouillard, R. Chemical Structure of Anthocyanins; Academic Press: New York, NY, USA, 1982; Volume 1.

24. Jordheim, M. Basic Anthocyanin Chemistry and Dietary Sources; CRC Press: Boca Raton, FL, USA, 2013; pp. 13-90. ISBN 978-1-4398-9471-2.

25. Lawrence, W.J.C.; Price, J.R.; Robinson, G.M.; Robinson, R. The distribution of anthocyanins in flowers, fruits and leaves. Philos. Trans. R. Soc. Lond. B. Biol. Sci. 1939, 230, 149-178.

26. Timberlake, C.F.; Bridle, P. Distribution of Anthocyanins in Food Plants; Academic Press: New York, NY, USA, 1982.

27. Dini, C.; Zaro, M.J.; Viña, S.Z. Bioactivity and functionality of anthocyanins: A review. Curr. Bioact. Compd. 2018, 15, 507-523. [CrossRef]

28. Tang, B.; Li, L.; Hu, Z.; Chen, Y.; Tan, T.; Jia, Y.; Xie, Q.; Chen, G. Anthocyanin accumulation and transcriptional regulation of anthocyanin biosynthesis in purple pepper. J. Agric. Food Chem. 2020, 68, 12152-12163. [CrossRef] [PubMed]

29. Pervaiz, T.; Songtao, J.; Faghihi, F.; Haider, M.S.; Fang, J. Naturally occurring anthocyanin, structure, functions and biosynthetic pathway in fruit plants. J. Plant Biochem. Physiol. 2017, 5, 1-9. [CrossRef]

30. Saigo, T.; Wang, T.; Watanabe, M.; Tohge, T. Diversity of anthocyanin and proanthocyanin biosynthesis in land plants. Curr. Opin. Plant Biol. 2020, 55, 93-99. [CrossRef] [PubMed]

31. Crozier, A.; Yokota, T.; Jaganath, I.B.; Marks, S.; Saltmarsh, M.; Clifford, M.N. Secondary Metabolites in Fruits, Vegetables, Beverages and Other Plant-based Dietary Components. In Plant Secondary Metabolites; Blackwell Publishing Ltd.: Oxford, UK, 2006; pp. 208-302.

32. Markakis, P. Anthocyanins as Food Colors; Elsevier: Amsterdam, The Netherlands, 2012; ISBN 0323157904.

33. Castañeda-Ovando, A.; de Lourdes Pacheco-Hernández, M.; Páez-Hernández, M.E.; Rodríguez, J.A.; Galán-Vidal, C.A. Chemical studies of anthocyanins: A review. Food Chem. 2009, 113, 859-871. [CrossRef]

34. Holton, T.A.; Cornish, E.C. Genetics and biochemistry of anthocyanin biosynthesis. Plant Cell 1995, 7, 1071. [CrossRef] [PubMed]

35. Tanaka, Y.; Sasaki, N.; Ohmiya, A. Biosynthesis of plant pigments: Anthocyanins, betalains and carotenoids. Plant J. 2008, 54, 733-749. [CrossRef] [PubMed] 
36. Yonekura-Sakakibara, K.; Nakayama, T.; Yamazaki, M.; Saito, K. Modification and stabilization of anthocyanins. In Anthocyanins; Springer: Berlin, Germany, 2008; pp. 169-190.

37. Passeri, V.; Koes, R.; Quattrocchio, F.M. New Challenges for the design of high value plant products: Stabilization of anthocyanins in plant vacuoles. Front. Plant Sci. 2016, 7, 153. [CrossRef] [PubMed]

38. Poustka, F.; Irani, N.G.; Feller, A.; Lu, Y.; Pourcel, L.; Frame, K.; Grotewold, E. A trafficking pathway for anthocyanins overlaps with the endoplasmic reticulum-to-vacuole protein-sorting route in Arabidopsis and contributes to the formation of vacuolar inclusions. Plant Physiol. 2007, 145, 1323-1335. [CrossRef]

39. Bendokas, V.; Skemiene, K.; Trumbeckaite, S.; Stanys, V.; Passamonti, S.; Borutaite, V.; Liobikas, J. Anthocyanins: From plant pigments to health benefits at mitochondrial level. Crit. Rev. Food Sci. Nutr. 2020, 60, 3352-3365. [CrossRef]

40. Rudall, P.J. Colourful cones: How did flower colour first evolve? J. Exp. Bot. 2020, 71, 759-767. [CrossRef]

41. Delgado-Vargas, F.; Jiménez, A.R.; Paredes-López, O. Natural pigments: Carotenoids, anthocyanins, and betalainsCharacteristics, biosynthesis, processing, and stability. Crit. Rev. Food Sci. Nutr. 2000, 40, 173-289. [CrossRef]

42. Rodrigues, R.F.; da Silva, P.F.; Shimizu, K.; Freitas, A.A.; Kovalenko, S.A.; Ernsting, N.P.; Quina, F.H.; Maçanita, A. Ultrafast internal conversion in a model anthocyanin-polyphenol complex: Implications for the biological role of anthocyanins in vegetative tissues of plants. Chemistry 2009, 15, 1397-1402. [CrossRef] [PubMed]

43. Fogelman, E.; Oren-Shamir, M.; Hirschberg, J.; Mandolino, G.; Parisi, B.; Ovadia, R.; Tanami, Z.; Faigenboim, A.; Ginzberg, I. Nutritional value of potato (Solanum tuberosum) in hot climates: Anthocyanins, carotenoids, and steroidal glycoalkaloids. Planta 2019, 249, 1143-1155. [CrossRef] [PubMed]

44. Steyn, W.J.J.; Wand, S.J.E.E.; Holcroft, D.M.; Jacobs, G. Anthocyanins in vegetative tissues: A proposed unified function in photoprotection. New Phytol. 2002, 155, 349-361. [CrossRef]

45. Del Valle, J.C.; Buide, M.L.M.L.; Whittall, J.B.; Valladares, F.; Narbona, E. UV radiation increases phenolic compound protection but decreases reproduction in Silene littorea. PLoS ONE 2020, 15, e0231611. [CrossRef] [PubMed]

46. Foyer, C.H.; Lelandais, M.; Kunert, K.J. Photooxidative stress in plants. Physiol. Plant. 1994, 92, 696-717. [CrossRef]

47. Zheng, X.-T.T.; Yu, Z.-C.C.; Tang, J.-W.W.; Cai, M.-L.L.; Chen, Y.-L.L.; Yang, C.-W.W.; Chow, W.S.; Peng, C.-L.L. The major photoprotective role of anthocyanins in leaves of Arabidopsis thaliana under long-term high light treatment: Antioxidant or light attenuator? Photosynth. Res. 2020, 1-6. [CrossRef]

48. Barker, D.H.; Seaton, G.G.R.; Robinson, S.A. Internal and external photoprotection in developing leaves of the CAM plant Cotyledon orbiculata. Plant Cell Environ. 1997, 20, 617-624. [CrossRef]

49. Ko, S.-S.; Jhong, C.-M.; Lin, Y.-J.; Wei, C.-Y.; Lee, J.-Y.; Shih, M.-C. Blue light mediates chloroplast avoidance and enhances photoprotection of vanilla orchid. Int. J. Mol. Sci. 2020, 21, 8022. [CrossRef] [PubMed]

50. Merzlyak, M.N.; Chivkunova, O.B. Light-stress-induced pigment changes and evidence for anthocyanin photoprotection in apples. J. Photochem. Photobiol. B Biol. 2000, 55, 155-163. [CrossRef]

51. Zarrouk, O.; Brunetti, C.; Egipto, R.; Pinheiro, C.; Genebra, T.; Gori, A.; Lopes, C.M.; Tattini, M.; Chaves, M.M. Grape ripening is regulated by deficit irrigation/elevated temperatures according to cluster position in the canopy. Front. Plant Sci. 2016, 7, 1640. [CrossRef] [PubMed]

52. De Leonardis, A.M.; Fragasso, M.; Beleggia, R.; Ficco, D.B.M.; de Vita, P.; Mastrangelo, A.M. Effects of heat stress on metabolite accumulation and composition, and nutritional properties of durum wheat grain. Int. J. Mol. Sci. 2015, 16, 30382-30404. [CrossRef] [PubMed]

53. Mena, P.; Galindo, A.; Collado-González, J.; Ondoño, S.; García-Viguera, C.; Ferreres, F.; Torrecillas, A.; Gil-Izquierdo, A. Sustained deficit irrigation affects the colour and phytochemical characteristics of pomegranate juice. J. Sci. Food Agric. 2013, 93, 1922-1927. [CrossRef] [PubMed]

54. Luna, M.C.; Bekhradi, F.; Ferreres, F.; Jordán, M.J.; Delshad, M.; Gil, M.I. Effect of water stress and storage time on anthocyanins and other phenolics of different genotypes of fresh sweet basil. J. Agric. Food Chem. 2015, 63, 9223-9231. [CrossRef]

55. Qi, T.; Song, S.; Ren, Q.; Wu, D.; Huang, H.; Chen, Y.; Fan, M.; Peng, W.; Ren, C.; Xie, D. The Jasmonate-ZIM-domain proteins interact with the WD-Repeat/bHLH/MYB complexes to regulate Jasmonate-mediated anthocyanin accumulation and trichome initiation in Arabidopsis thaliana. Plant Cell 2011, 23, 1795-1814. [CrossRef]

56. Song, S.; Qi, T.; Fan, M.; Zhang, X.; Gao, H.; Huang, H.; Wu, D.; Guo, H.; Xie, D. The bHLH subgroup IIId factors negatively regulate jasmonate-mediated plant defense and development. PLoS Genet. 2013, 9, e1003653. [CrossRef] [PubMed]

57. Nakata, M.; Mitsuda, N.; Herde, M.; Koo, A.J.K.; Moreno, J.E.; Suzuki, K.; Howe, G.A.; Ohme-Takagi, M. A bHLH-type transcription factor, aba-inducible bhlh-type transcription factor/ja-associated myc2-like1, acts as a repressor to negatively regulate jasmonate signaling in arabidopsis. Plant Cell 2013, 25, 1641-1656. [CrossRef] [PubMed]

58. Khonkhaeng, B.; Cherdthong, A. Improving nutritive value of purple field corn residue and rice straw by culturing with white-rot fungi. J. Fungi 2020, 6, 69. [CrossRef] [PubMed]

59. Lingua, G.; Bona, E.; Manassero, P.; Marsano, F.; Todeschini, V.; Cantamessa, S.; Copetta, A.; D'Agostino, G.; Gamalero, E.; Berta, G. Arbuscular mycorrhizal fungi and plant growth-promoting pseudomonads increases anthocyanin concentration in strawberry fruits (Fragaria x ananassa var. Selva) in conditions of reduced fertilization. Int. J. Mol. Sci. 2013, 14, 16207-16225. [CrossRef]

60. Wang, L.; Wang, B.; Yu, H.; Guo, H.; Lin, T.; Kou, L.; Wang, A.; Shao, N.; Ma, H.; Xiong, G.; et al. Transcriptional regulation of strigolactone signalling in Arabidopsis. Nature 2020, 583, 277-281. [CrossRef] [PubMed] 
61. Sakatani, M.; Suda, I.; Oki, T.; Kobayashi, S.; Kobayashi, S.; Takahashi, M. Effects of purple sweet potato anthocyanins on development and intracellular redox status of bovine preimplantation embryos exposed to heat shock. J. Reprod. Dev. 2007, 53, 605-614. [CrossRef] [PubMed]

62. Liu, Y.; Lin-Wang, K.; Espley, R.V.; Wang, L.; Li, Y.; Liu, Z.; Zhou, P.; Zeng, L.; Zhang, X.; Zhang, J. StMYB44 negatively regulates anthocyanin biosynthesis at high temperatures in tuber flesh of potato. J. Exp. Bot. 2019, 70, 3809-3824. [CrossRef] [PubMed]

63. Commisso, M.; Toffali, K.; Strazzer, P.; Stocchero, M.; Ceoldo, S.; Baldan, B.; Levi, M.; Guzzo, F. Impact of phenylpropanoid compounds on heat stress tolerance in carrot cell cultures. Front. Plant Sci. 2016, 7, 1439. [CrossRef] [PubMed]

64. Dela, G.; Or, E.; Ovadia, R.; Nissim-Levi, A.; Weiss, D.; Oren-Shamir, M. Changes in anthocyanin concentration and composition in 'Jaguar'rose flowers due to transient high-temperature conditions. Plant Sci. 2003, 164, 333-340. [CrossRef]

65. Wu, X.; Zhang, S.; Liu, X.; Shang, J.; Zhang, A.; Zhu, Z.; Zha, D. Chalcone synthase (CHS) family members analysis from eggplant (Solanum melongena L.) in the flavonoid biosynthetic pathway and expression patterns in response to heat stress. PLoS ONE 2020, $15, \mathrm{e} 0226537$.

66. Zhang, S.; Zhang, A.; Wu, X.; Zhu, Z.; Yang, Z.; Zhu, Y.; Zha, D. Transcriptome analysis revealed expression of genes related to anthocyanin biosynthesis in eggplant (Solanum melongena L.) under high-temperature stress. BMC Plant Biol. 2019, 19, 1-13. [CrossRef] [PubMed]

67. Wu, X.; Zhang, A.; Zhu, Z.; Yao, J.; Zha, D.; Li, X. Effects of high-temperature stress on active oxygen metabolism, anthocyanin content and its main synthases in eggplant peel. Acta Agric. Jiangxi 2018, 30, 1-5.

68. Zhang, A.; Zhu, Z.; Shang, J.; Zhang, S.; Shen, H.; Wu, X.; Zha, D. Transcriptome profiling and gene expression analyses of eggplant (Solanum melongena L.) under heat stress. PLoS ONE 2020, 15, e0236980. [CrossRef] [PubMed]

69. Wahid, A. Physiological implications of metabolite biosynthesis for net assimilation and heat-stress tolerance of sugarcane (Saccharum officinarum) sprouts. J. Plant Res. 2007, 120, 219-228. [CrossRef]

70. Shao, L.; Shu, Z.; Sun, S.; Peng, C.; Wang, X.; Lin, Z. Antioxidation of anthocyanins in photosynthesis under high temperature stress. J. Integr. Plant Biol. 2007, 49, 1341-1351. [CrossRef]

71. Shen, J.; Zhang, D.; Zhou, L.; Zhang, X.; Liao, J.; Duan, Y.; Wen, B.; Ma, Y.; Wang, Y.; Fang, W.; et al. Transcriptomic and metabolomic profiling of Camellia sinensis L. cv. "Suchazao" exposed to temperature stresses reveals modification in protein synthesis and photosynthetic and anthocyanin biosynthetic pathways. Tree Physiol. 2019, 39, 1583-1599. [CrossRef] [PubMed]

72. Chopra, R.; Burow, G.; Burke, J.J.; Gladman, N.; Xin, Z. Genome-wide association analysis of seedling traits in diverse Sorghum germplasm under thermal stress. BMC Plant Biol. 2017, 17, 12. [CrossRef] [PubMed]

73. Rienth, M.; Torregrosa, L.; Luchaire, N.; Chatbanyong, R.; Lecourieux, D.; Kelly, M.T.; Romieu, C. Day and night heat stress trigger different transcriptomic responses in green and ripening grapevine (vitis vinifera) fruit. BMC Plant Biol. 2014, 14, 108. [CrossRef] [PubMed]

74. Zhang, X.; Rerksiri, W.; Liu, A.; Zhou, X.; Xiong, H.; Xiang, J.; Chen, X.; Xiong, X. Transcriptome profile reveals heat response mechanism at molecular and metabolic levels in rice flag leaf. Gene 2013, 530, 185-192. [CrossRef] [PubMed]

75. Yu, M.; Man, Y.; Wang, Y. Light- and temperature-induced expression of an R2R3-MYB gene regulates anthocyanin biosynthesis in red-fleshed kiwifruit. Int. J. Mol. Sci. 2019, 20, 5228. [CrossRef]

76. Kim, S.; Hwang, G.; Lee, S.; Zhu, J.-Y.; Paik, I.; Nguyen, T.T.; Kim, J.; Oh, E. High ambient temperature represses anthocyanin biosynthesis through degradation of HY5. Front. Plant Sci. 2017, 8, 1787. [CrossRef]

77. Correia, B.; Rodriguez, J.L.; Valledor, L.; Almeida, T.; Santos, C.; Cañal, M.J.; Pinto, G. Analysis of the expression of putative heat-stress related genes in relation to thermotolerance of cork oak. J. Plant Physiol. 2014, 171, 399-406. [CrossRef] [PubMed]

78. Li, J.; Ren, L.; Gao, Z.; Jiang, M.; Liu, Y.; Zhou, L.; He, Y.; Chen, H. Combined transcriptomic and proteomic analysis constructs a new model for light-induced anthocyanin biosynthesis in eggplant (Solanum melongena L.). Plant. Cell Environ. 2017, 40, 3069-3087. [CrossRef]

79. Jiang, M.; Ren, L.; Lian, H.; Liu, Y.; Chen, H. Novel insight into the mechanism underlying light-controlled anthocyanin accumulation in eggplant (Solanum melongena L.). Plant Sci. 2016, 249, 46-58. [CrossRef] [PubMed]

80. Li, J.; He, Y.-J.; Zhou, L.; Liu, Y.; Jiang, M.; Ren, L.; Chen, H. Transcriptome profiling of genes related to light-induced anthocyanin biosynthesis in eggplant (Solanum melongena L.) before purple color becomes evident. BMC Genom. 2018, 19, 1-12. [CrossRef] [PubMed]

81. Ko, S.-S.; Jhong, C.-M.; Shih, M.-C. Blue light acclimation reduces the photoinhibition of phalaenopsis aphrodite (moth Orchid). Int. J. Mol. Sci. 2020, 21, 6167. [CrossRef] [PubMed]

82. Koyama, T.; Sato, F. The function of ETHYLENE RESPONSE FACTOR genes in the light-induced anthocyanin production of Arabidopsis thaliana leaves. Plant Biotechnol. 2018, 35, 87-91. [CrossRef]

83. Lotkowska, M.E.; Tohge, T.; Fernie, A.R.; Xue, G.-P.; Balazadeh, S.; Mueller-Roeber, B. The Arabidopsis transcription factor MYB112 promotes anthocyanin formation during salinity and under high light stress. Plant Physiol. 2015, 169, 1862-1880. [CrossRef] [PubMed]

84. Woo, N.S.; Gordon, M.J.; Graham, S.R.; Rossel, J.B.; Badger, M.R.; Pogson, B.J. A mutation in the purine biosynthetic enzyme ATASE2 impacts high light signalling and acclimation responses in green and chlorotic sectors of Arabidopsis leaves. Funct. Plant Biol. 2011, 38, 401-419. [CrossRef] [PubMed]

85. Pfab, A.; Breindl, M.; Grasser, K.D. The Arabidopsis histone chaperone FACT is required for stress-induced expression of anthocyanin biosynthetic genes. Plant Mol. Biol. 2018, 96, 367-374. [CrossRef] [PubMed] 
86. Hong, Y.; Li, M.; Dai, S. iTRAQ-based protein profiling provides insights into the mechanism of light-induced anthocyanin biosynthesis in chrysanthemum (Chrysanthemum $\times$ morifolium). Genes 2019, 10, 1024. [CrossRef]

87. Wang, J.; Guo, M.; Li, Y.; Wu, R.; Zhang, K. High-throughput transcriptome sequencing reveals the role of anthocyanin metabolism in begonia semperflorens under high light stress. Photochem. Photobiol. 2018, 94, 105-114. [CrossRef]

88. Zhu, H.; Li, X.; Zhai, W.; Liu, Y.; Gao, Q.; Liu, J.; Ren, L.; Chen, H.; Zhu, Y. Effects of low light on photosynthetic properties, antioxidant enzyme activity, and anthocyanin accumulation in purple pak-choi (Brassica campestris ssp. Chinensis Makino). PLoS ONE 2017, 12, e0179305. [CrossRef] [PubMed]

89. Miki, S.; Wada, K.C.; Takeno, K. A possible role of an anthocyanin filter in low-intensity light stress-induced flowering in Perilla frutescens var. crispa. J. Plant Physiol. 2015, 175, 157-162. [CrossRef] [PubMed]

90. Wada, K.C.; Kondo, H.; Takeno, K. Obligatory short-day plant, Perilla frutescens var. crispa can flower in response to low-intensity light stress under long-day conditions. Physiol. Plant. 2010, 138, 339-345. [CrossRef] [PubMed]

91. Carpenter, K.L.; Keidel, T.S.; Pihl, M.C.; Hughes, N.M. Support for a photoprotective function of winter leaf reddening in nitrogen-deficient individuals of Lonicera japonica. Molecules 2014, 19, 17810-17828. [CrossRef] [PubMed]

92. Steyn, W.J.; Wand, S.J.E.; Jacobs, G.; Rosecrance, R.C.; Roberts, S.C. Evidence for a photoprotective function of low-temperatureinduced anthocyanin accumulation in apple and pear peel. Physiol. Plant. 2009, 136, 461-472. [CrossRef] [PubMed]

93. Cheruiyot, E.K.; Mumera, L.M.; Ng'etich, W.K.; Hassanali, A.; Wachira, F. Polyphenols as potential indicators for drought tolerance in tea (Camellia sinensis L.). Biosci. Biotechnol. Biochem. 2007, 71, 707310505. [CrossRef]

94. Griesser, M.; Weingart, G.; Schoedl-Hummel, K.; Neumann, N.; Becker, M.; Varmuza, K.; Liebner, F.; Schuhmacher, R.; Forneck, A. Severe drought stress is affecting selected primary metabolites, polyphenols, and volatile metabolites in grapevine leaves (Vitis vinifera cv. Pinot noir). Plant Physiol. Biochem. 2015, 88, 17-26. [CrossRef] [PubMed]

95. Hinojosa-Gómez, J.; San Martín-Hernández, C.; Heredia, J.B.; León-Félix, J.; Osuna-Enciso, T.; Muy-Rangel, M.D. Anthocyanin induction by drought stress in the calyx of roselle cultivars. Molecules 2020, 25, 1555. [CrossRef] [PubMed]

96. Faghih, S.; Zamani, Z.; Fatahi, R.; Liaghat, A. Effects of deficit irrigation and kaolin application on vegetative growth and fruit traits of two early ripening apple cultivars. Biol. Res. 2019, 52, 43. [CrossRef] [PubMed]

97. Adak, N.; Gubbuk, H.; Tetik, N. Yield, quality and biochemical properties of various strawberry cultivars under water stress. J. Sci. Food Agric. 2018, 98, 304-311. [CrossRef]

98. Kamali, S.; Mehraban, A. Nitroxin and arbuscular mycorrhizal fungi alleviate negative effects of drought stress on Sorghum bicolor yield through improving physiological and biochemical characteristics. Plant Signal. Behav. 2020, 15, 1813998. [CrossRef]

99. Tisarum, R.; Theerawitaya, C.; Samphumphuang, T.; Phisalaphong, M.; Singh, H.P.; Cha-Um, S. Promoting water deficit tolerance and anthocyanin fortification in pigmented rice cultivar (Oryza sativa L. subsp. indica) using arbuscular mycorrhizal fungi inoculation. Physiol. Mol. Biol. Plants Int. J. Funct. Plant Biol. 2019, 25, 821-835. [CrossRef] [PubMed]

100. Loubser, J.; Hills, P. The application of a commercially available citrus-based extract mitigates moderate NaCl-Stress in arabidopsis thaliana plants. Plants 2020, 9, 1010. [CrossRef]

101. Jeong, C.Y.; Lee, W.J.; Truong, H.A.; Trịnh, C.S.; Jin, J.Y.; Kim, S.; Hwang, K.Y.; Kang, C.-S.; Moon, J.-K.; Hong, S.-W.; et al. Dual role of SND1 facilitates efficient communication between abiotic stress signalling and normal growth in Arabidopsis. Sci. Rep. 2018, 8, 10114. [CrossRef] [PubMed]

102. Van Oosten, M.J.; Sharkhuu, A.; Batelli, G.; Bressan, R.A.; Maggio, A. The Arabidopsis thaliana mutant air1 implicates SOS3 in the regulation of anthocyanins under salt stress. Plant Mol. Biol. 2013, 83, 405-415. [CrossRef] [PubMed]

103. Naing, A.H.; Park, K.I.; Ai, T.N.; Chung, M.Y.; Han, J.S.; Kang, Y.-W.; Lim, K.B.; Kim, C.K. Overexpression of snapdragon Delila (Del) gene in tobacco enhances anthocyanin accumulation and abiotic stress tolerance. BMC Plant Biol. 2017, 17, 65. [CrossRef] [PubMed]

104. Trivellini, A.; Gordillo, B.; Rodríguez-Pulido, F.J.; Borghesi, E.; Ferrante, A.; Vernieri, P.; Quijada-Morín, N.; González-Miret, M.L.; Heredia, F.J. Effect of salt stress in the regulation of anthocyanins and color of hibiscus flowers by digital image analysis. J. Agric. Food Chem. 2014, 62, 6966-6974. [CrossRef]

105. Garriga, M.; Retamales, J.B.; Romero-Bravo, S.; Caligari, P.D.S.; Lobos, G.A. Chlorophyll, anthocyanin, and gas exchange changes assessed by spectroradiometry in Fragaria chiloensis under salt stress. J. Integr. Plant Biol. 2014, 56, 505-515. [CrossRef] [PubMed]

106. Tisarum, R.; Theerawitaya, C.; Samphumphuang, T.; Polispitak, K.; Thongpoem, P.; Singh, H.P.; Cha-Um, S. Alleviation of salt stress in upland rice (Oryza sativa L. ssp. indica cv. Leum Pua) using arbuscular mycorrhizal fungi inoculation. Front. Plant Sci. 2020, 11, 348. [CrossRef]

107. Cheng, Y.-J.; Kim, M.-D.; Deng, X.-P.; Kwak, S.-S.; Chen, W. Enhanced salt stress tolerance in transgenic potato plants expressing IbMYB1, a sweet potato transcription factor. J. Microbiol. Biotechnol. 2013, 23, 1737-1746. [CrossRef]

108. Appel, H.M.; Cocroft, R.B. Plants respond to leaf vibrations caused by insect herbivore chewing. Oecologia 2014, 175, 1257-1266. [CrossRef] [PubMed]

109. Li, X.; Ouyang, X.; Zhang, Z.; He, L.; Wang, Y.; Li, Y.; Zhao, J.; Chen, Z.; Wang, C.; Ding, L. Over-expression of the red plant gene R1 enhances anthocyanin production and resistance to bollworm and spider mite in cotton. Mol. Genet. Genom. 2019, 294, 469-478. [CrossRef] [PubMed]

110. Chen, S.; Lin, I.W.; Chen, X.; Huang, Y.; Chang, S.; Lo, H.; Lu, H.; Yeh, K. Sweet potato NAC transcription factor, Ib NAC 1 , upregulates sporamin gene expression by binding the SWRE motif against mechanical wounding and herbivore attack. Plant $J$. 2016, 86, 234-248. [CrossRef] [PubMed] 
111. Costa-Arbulú, C.; Gianoli, E.; Gonzáles, W.L.; Niemeyer, H.M. Feeding by the aphid Sipha flava produces a reddish spot on leaves of Sorghum halepense: An induced defense. J. Chem. Ecol. 2001, 27, 273-283. [CrossRef]

112. Fischer, T.C.; Mirbeth, B.; Rentsch, J.; Sutter, C.; Ring, L.; Flachowsky, H.; Habegger, R.; Hoffmann, T.; Hanke, M.; Schwab, W. Premature and ectopic anthocyanin formation by silencing of anthocyanidin reductase in strawberry (Fragaria $\times$ ananassa). New Phytol. 2014, 201, 440-451. [CrossRef]

113. Koski, T.-M.; Kalpio, M.; Laaksonen, T.; Sirkiä, P.M.; Kallio, H.P.; Yang, B.; Linderborg, K.M.; Klemola, T. Effects of insect herbivory on bilberry production and removal of berries by frugivores. J. Chem. Ecol. 2017, 43, 422-432. [CrossRef] [PubMed]

114. Liu, Y.; Li, M.; Li, T.; Chen, Y.; Zhang, L.; Zhao, G.; Zhuang, J.; Zhao, W.; Gao, L.; Xia, T. Airborne fungus-induced biosynthesis of anthocyanins in Arabidopsis thaliana via jasmonic acid and salicylic acid signaling. Plant Sci. 2020, 300, 110635. [CrossRef]

115. Venneman, J.; Vandermeersch, L.; Walgraeve, C.; Audenaert, K.; Ameye, M.; Verwaeren, J.; Steppe, K.; Van Langenhove, H.; Haesaert, G.; Vereecke, D.; et al. Respiratory $\mathrm{CO}(2)$ combined with a blend of volatiles emitted by endophytic serendipita strains strongly stimulate growth of arabidopsis implicating auxin and cytokinin signaling. Front. Plant Sci. 2020, 11, 544435. [CrossRef]

116. Todeschini, V.; AitLahmidi, N.; Mazzucco, E.; Marsano, F.; Gosetti, F.; Robotti, E.; Bona, E.; Massa, N.; Bonneau, L.; Marengo, E.; et al. Impact of beneficial microorganisms on strawberry growth, fruit production, nutritional quality, and volatilome. Front. Plant Sci. 2018, 9, 1611. [CrossRef]

117. Parada, J.; Valenzuela, T.; Gómez, F.; Tereucán, G.; García, S.; Cornejo, P.; Winterhalter, P.; Ruiz, A. Effect of fertilization and arbuscular mycorrhizal fungal inoculation on antioxidant profiles and activities in Fragaria ananassa fruit. J. Sci. Food Agric. 2019, 99, 1397-1404. [CrossRef]

118. Teixeira, C.S.P.; Lucas, R.J.; Olykan, S.T.; Moot, D.J. Causes of leaf reddening in subterranean clover cultivars. New Zeal. J. Agric. Res. 2020, 63, 315-331. [CrossRef]

119. Matile, P. Biochemistry of Indian summer: Physiology of autumnal leaf coloration. Exp. Gerontol. 2000, 35, 145-158. [CrossRef]

120. Wagner, R.J.; Wagner, A.B.; Howard, R.A. The ecology of an elfin forest in Puerto Rico, 9. Chemical studies of colored leaves. J. Arnold Arbor. 1969, 50, 556-565.

121. Lee, D.W.; Brammeier, S.; Smith, A.P. The selective advantages of anthocyanins in developing leaves of mango and cacao. Biotropica 1987, 19, 40-49. [CrossRef]

122. Sturgeon, K.B.; Mitton, J.B. Cone color polymorphism associated with elevation in white fir, Abies concolor, in southern Colorado. Am. J. Bot. 1980, 67, 1040-1045. [CrossRef]

123. McClure, J.W. Physiology and functions of flavonoids. In The Flavonoids; Springer: Berlin, Germany, 1975; pp. $970-1055$.

124. Saunders, J.A.; McClure, J.W. The distribution of flavonoids in chloroplasts of twenty five species of vascular plants. Phytochemistry 1976, 15, 809-810. [CrossRef]

125. Chalker-Scott, L.; Chalker-Scott, L. Environmental significance of anthocyanins in plant stress responses. Photochem. Photobiol. 1999, 70, 1-9. [CrossRef]

126. Weger, H.G.; Silim, S.N.; Guy, R.D. Photosynthetic acclimation to low temperature by western red cedar seedlings. Plant. Cell Environ. 1993, 16, 711-717. [CrossRef]

127. Simko, I.; Hayes, R.J.; Furbank, R.T. Non-destructive phenotyping of lettuce plants in early stages of development with optical sensors. Front. Plant Sci. 2016, 7, 1985. [CrossRef]

128. Wingler, A.; Tijero, V.; Müller, M.; Yuan, B.; Munné-Bosch, S. Interactions between sucrose and jasmonate signalling in the response to cold stress. BMC Plant Biol. 2020, 20, 176. [CrossRef]

129. Sperdouli, I.; Moustakas, M. Interaction of proline, sugars, and anthocyanins during photosynthetic acclimation of Arabidopsis thaliana to drought stress. J. Plant Physiol. 2012, 169, 577-585. [CrossRef] [PubMed]

130. Hughes, N.M.; Neufeld, H.S.; Burkey, K.O. Functional role of anthocyanins in high-light winter leaves of the evergreen herb Galax urceolata. New Phytol. 2005, 168, 575-587. [CrossRef]

131. Wen, B.; Xiao, W.; Mu, Q.; Li, D.; Chen, X.; Wu, H.; Li, L.; Peng, F. How does nitrate regulate plant senescence? Plant Physiol. Biochem. PPB 2020, 157, 60-69. [CrossRef] [PubMed]

132. Masclaux-Daubresse, C. Autophagy controls carbon, nitrogen, and redox homeostasis in plants. Autophagy 2016, $12,896-897$. [CrossRef]

133. Thomas, H.; Huang, L.; Young, M.; Ougham, H. Evolution of plant senescence. BMC Evol. Biol. 2009, 9, 163. [CrossRef] [PubMed]

134. Hoch, W.A.; Zeldin, E.L.; McCown, B.H. Physiological significance of anthocyanins during autumnal leaf senescence. Tree Physiol. 2001, 21, 1-8. [CrossRef] [PubMed]

135. Tallis, M.J.; Lin, Y.; Rogers, A.; Zhang, J.; Street, N.R.; Miglietta, F.; Karnosky, D.F.; De Angelis, P.; Calfapietra, C.; Taylor, G. The transcriptome of populus in elevated CO reveals increased anthocyanin biosynthesis during delayed autumnal senescence. New Phytol. 2010, 186, 415-428. [CrossRef] [PubMed]

136. Dhar, N.; Caruana, J.; Erdem, I.; Subbarao, K.V.; Klosterman, S.J.; Raina, R. The Arabidopsis senescence-associated gene 13 regulates dark-induced senescence and plays contrasting roles in defense against bacterial and fungal pathogens. Mol. Plant. Microbe. Interact. 2020, 33, 754-766. [CrossRef]

137. Masclaux-Daubresse, C.; Clément, G.; Anne, P.; Routaboul, J.-M.; Guiboileau, A.; Soulay, F.; Shirasu, K.; Yoshimoto, K. Stitching together the multiple dimensions of autophagy using metabolomics and transcriptomics reveals impacts on metabolism, development, and plant responses to the environment in Arabidopsis. Plant Cell 2014, 26, 1857-1877. [CrossRef] 
138. Bárcena, A.; Martínez, G.; Costa, L. Low intensity light treatment improves purple kale (Brassica oleracea var. sabellica) postharvest preservation at room temperature. Heliyon 2019, 5, e02467. [CrossRef]

139. Liang, D.; Shen, Y.; Ni, Z.; Wang, Q.; Lei, Z.; Xu, N.; Deng, Q.; Lin, L.; Wang, J.; Lv, X.; et al. Exogenous melatonin application delays senescence of kiwifruit leaves by regulating the antioxidant capacity and biosynthesis of flavonoids. Front. Plant Sci. 2018, 9, 426. [CrossRef] [PubMed]

140. Nagira, Y.; Ikegami, K.; Koshiba, T.; Ozeki, Y. Effect of ABA upon anthocyanin synthesis in regenerated torenia shoots. J. Plant Res. 2006, 119, 137-144. [CrossRef] [PubMed]

141. Botha, C.E.J.; Cross, R.H.M.; Van Bel, A.J.E.; Peter, C.I. Phloem loading in the sucrose-export-defective (SXD-1) mutant maize is limited by callose deposition at plasmodesmata in bundle sheath-Vascular parenchyma interface. Protoplasma 2000, 214, 65-72 [CrossRef]

142. Russin, W.A.; Evert, R.F.; Vanderveer, P.J.; Sharkey, T.D.; Briggs, S.P. Modification of a specific class of plasmodesmata and loss of sucrose export ability in the sucrose export defective1 maize mutant. Plant Cell 1996, 8, 645-658. [CrossRef]

143. Castellarin, S.D.; Gambetta, G.A.; Wada, H.; Shackel, K.A.; Matthews, M.A. Fruit ripening in Vitis vinifera: Spatiotemporal relationships among turgor, sugar accumulation, and anthocyanin biosynthesis. J. Exp. Bot. 2011, 62, 4345-4354. [CrossRef]

144. Lecourieux, F.; Kappel, C.; Lecourieux, D.; Serrano, A.; Torres, E.; Arce-Johnson, P.; Delrot, S. An update on sugar transport and signalling in grapevine. J. Exp. Bot. 2014, 65, 821-832. [CrossRef]

145. Boss, P.K.; Davies, C. Molecular biology of sugar and anthocyanin accumulation in grape berries. In Molecular Biology $\mathcal{E}$ Biotechnology of the Grapevine; Springer: Berlin, Germany, 2001; pp. 1-33.

146. Chalker-Scott, L. Do anthocyanins function as osmoregulators in leaf tissues? Adv. Bot. Res. 2002, 37, $104-129$.

147. Hughes, N.M.; Reinhardt, K.; Feild, T.S.; Gerardi, A.R.; Smith, W.K. Association between winter anthocyanin production and drought stress in angiosperm evergreen species. J. Exp. Bot. 2010, 61, 1699-1709. [CrossRef]

148. Sherwin, H.W.; Farrant, J.M. Protection mechanisms against excess light in the resurrection plants Craterostigma wilmsii and Xerophyta viscosa. Plant Growth Regul. 1998, 24, 203-210. [CrossRef]

149. Roby, G.; Harbertson, J.F.; Adams, D.A.; Matthews, M.A. Berry size and vine water deficits as factors in winegrape composition: Anthocyanins and tannins. Aust. J. Grape Wine Res. 2004, 10, 100-107. [CrossRef]

150. Hirasuna, T.J.; Shuler, M.L.; Lackney, V.K.; Spanswick, R.M. Enhanced anthocyanin production in grape cell cultures. Plant Sci. 1991, 78, 107-120. [CrossRef]

151. Suzuki, M. Enhancement of anthocyanin accumulation by high osmotic stress and low pH in grape cells (Vitis hybrids). J. Plant Physiol. 1995, 147, 152-155. [CrossRef]

152. Sato, K.; Nakayama, M.; Shigeta, J. Culturing conditions affecting the production of anthocyanin in suspended cell cultures of strawberry. Plant Sci. 1996, 113, 91-98. [CrossRef]

153. Tholakalabavi, A.; Zwiazek, J.J.; Thorpe, T.A. Osmotically-stressed poplar cell cultures: Anthocyanin accumulation, deaminase activity, and solute composition. J. Plant Physiol. 1997, 151, 489-496. [CrossRef]

154. Janzen, D.H. New Horizons in the Biology of Plant Defenses; Cmabridge University Press: Cambridge, UK, 1979.

155. Gould, K.S.; Kuhn, D.N.; Lee, D.W.; Oberbauer, S.F. Why leaves are sometimes red. Nature 1995, 378, 241-242. [CrossRef]

156. Feild, T.S.; Lee, D.W.; Holbrook, N.M. Why leaves turn red in autumn. The role of anthocyanins in senescing leaves of red-osier dogwood. Plant Physiol. 2001, 127, 566-574. [CrossRef]

157. Hamilton, W.D.; Brown, S.P. Autumn tree colours as a handicap signal. Proc. R. Soc. Lond. Ser. B Biol. Sci. 2001, $268,1489-1493$. [CrossRef]

158. Coley, P.D.; Aide, T.M. Red coloration of tropical young leaves: A possible antifungal defence? J. Trop. Ecol. 1989, 5, 293-300. [CrossRef]

159. Stone, B.C. Protective Coloration of Young Leaves in Certain Malaysian Palms. Biotropica 1979, 11, 26. [CrossRef]

160. Givnish, T.J. Leaf mottling: Relation to growth form and leaf phenology and possible role as camouflage. Funct. Ecol. 1990, 463-474. [CrossRef]

161. Lee, D.W. The spectral distribution of radiation in two neotropical rainforests. Biotropica 1987, 19, 161-166. [CrossRef]

162. Close, D.C.; Beadle, C.L. The ecophysiology of foliar anthocyanin. Bot. Rev. 2003, 69, 149-161. [CrossRef]

163. Neill, S.; Gould, K.S. Optical properties of leaves in relation to anthocyanin concentration and distribution. Can. J. Bot. 2000, 77, 1777-1782. [CrossRef]

164. Pietrini, F.; Iannelli, M.A.; Massacci, A. Anthocyanin accumulation in the illuminated surface of maize leaves enhances protection from photo-inhibitory risks at low temperature, without further limitation to photosynthesis. Plant. Cell Environ. 2002, 25, 1251-1259. [CrossRef]

165. Mannino, G.; Perrone, A.; Campobenedetto, C.; Schittone, A.; Margherita Bertea, C.; Gentile, C. Phytochemical profile and antioxidative properties of Plinia trunciflora fruits: A new source of nutraceuticals. Food Chem. 2020, 307, 125515. [CrossRef]

166. Mazza, G. Anthocyanins in Fruits, Vegetables, and Grains; CRC Press: Boca Raton, FL, USA, 2018; ISBN 135108660X.

167. Aadil, R.M.; Zeng, X.-A.; Jabbar, S.; Nazir, A.; Mann, A.A.; Khan, M.K.I.; Ramzan, A. Quality evaluation of grapefruit juice by thermal and high pressure processing treatment. Pak. J. Agric. Res. 2017, 30, 249-257. [CrossRef]

168. Chong, M.F.F.; MacDonald, R.; Lovegrove, J.A. Fruit polyphenols and CVD risk: A review of human intervention studies. Br. J. Nutr. 2010, 104, S28-S39. [CrossRef] [PubMed] 
169. Al-Farsi, M.; Alasalvar, C.; Morris, A.; Baron, M.; Shahidi, F. Comparison of antioxidant activity, anthocyanins, carotenoids, and phenolics of three native fresh and sun-dried date (Phoenix dactylifera L.) varieties grown in Oman. J. Agric. Food Chem. 2005, 53, 7592-7599. [CrossRef]

170. Solomon, A.; Golubowicz, S.; Yablowicz, Z.; Grossman, S.; Bergman, M.; Gottlieb, H.E.; Altman, A.; Kerem, Z.; Flaishman, M.A. Antioxidant activities and anthocyanin content of fresh fruits of common fig (Ficus carica L.). J. Agric. Food Chem. 2006, 54, 7717-7723. [CrossRef] [PubMed]

171. Kulling, S.E.; Rawel, H.M. Chokeberry (Aronia melanocarpa)-A review on the characteristic components and potential health effects. Planta Med. 2008, 74, 1625-1634. [CrossRef] [PubMed]

172. Francis, F.J.; Harborne, J.B. Anthocyanins of the garden huckleberry, Solanum guineese. J. Food Sci. 1966, 31, 524-528. [CrossRef]

173. Morissette, A.; Kropp, C.; Songpadith, J.-P.; Junges Moreira, R.; Costa, J.; Mariné Casadó, R.; Pilon, G.; Varin, T.V.; Dudonné, S.; Boutekrabt, L. Blueberry proanthocyanidins and anthocyanins improve metabolic health through a gut microbiota-dependent mechanism in diet-induced obese mice. Am. J. Physiol. Metab. 2020, 318, E965-E980. [CrossRef]

174. Bowen-Forbes, C.S.; Zhang, Y.; Nair, M.G. Anthocyanin content, antioxidant, anti-inflammatory and anticancer properties of blackberry and raspberry fruits. J. Food Compos. Anal. 2010, 23, 554-560. [CrossRef]

175. Gu, C.; Howell, K.; Dunshea, F.R.; Suleria, H.A.R. LC-ESI-QTOF/MS characterisation of phenolic acids and flavonoids in polyphenol-rich fruits and vegetables and their potential antioxidant activities. Antioxidants 2019, 8, 405. [CrossRef] [PubMed]

176. Zhang, Z.; Kou, X.; Fugal, K.; McLaughlin, J. Comparison of HPLC methods for determination of anthocyanins and anthocyanidins in bilberry extracts. J. Agric. Food Chem. 2004, 52, 688-691. [CrossRef] [PubMed]

177. Vigliante, I.; Mannino, G.; Maffei, M.E. OxiCyan ${ }^{\circledR}$, a phytocomplex of bilberry (Vaccinium myrtillus) and spirulina (Spirulina platensis), exerts both direct antioxidant activity and modulation of ARE/Nrf2 pathway in HepG2 cells. J. Funct. Foods 2019, 61, 103508. [CrossRef]

178. Wiczkowski, W.; Szawara-Nowak, D.; Topolska, J. Red cabbage anthocyanins: Profile, isolation, identification, and antioxidant activity. Food Res. Int. 2013, 51, 303-309. [CrossRef]

179. McDougall, G.J.; Fyffe, S.; Dobson, P.; Stewart, D. Anthocyanins from red cabbage-stability to simulated gastrointestinal digestion. Phytochemistry 2007, 68, 1285-1294. [CrossRef]

180. Yuan, Y.; Chiu, L.-W.; Li, L. Transcriptional regulation of anthocyanin biosynthesis in red cabbage. Planta 2009, $230,1141$. [CrossRef] [PubMed]

181. He, Q.; Zhang, Z.; Zhang, L. Anthocyanin accumulation, antioxidant ability and stability, and a transcriptional analysis of anthocyanin biosynthesis in purple heading Chinese cabbage (Brassica rapa L. ssp. pekinensis). J. Agric. Food Chem. 2016, 64, 132-145. [CrossRef] [PubMed]

182. Han, K.-H.; Sekikawa, M.; Shimada, K.; Hashimoto, M.; Hashimoto, N.; Noda, T.; Tanaka, H.; Fukushima, M. Anthocyanin-rich purple potato flake extract has antioxidant capacity and improves antioxidant potential in rats. Br. J. Nutr. 2006, 96, 1125-1134. [CrossRef] [PubMed]

183. Mannino, G.; Gentile, C.; Maffei, M.E. Chemical partitioning and DNA fingerprinting of some pistachio (Pistacia vera L.) varieties of different geographical origin. Phytochemistry 2019, 160, 40-47. [CrossRef]

184. Neveu, V.; Perez-Jiménez, J.; Vos, F.; Crespy, V.; du Chaffaut, L.; Mennen, L.; Knox, C.; Eisner, R.; Cruz, J.; Wishart, D.; et al. Phenol-Explorer: An online comprehensive database on polyphenol contents in foods. Database 2010, 2010, bap024. [CrossRef] [PubMed]

185. Rothwell, J.A.; Urpi-Sarda, M.; Boto-Ordoñez, M.; Knox, C.; Llorach, R.; Eisner, R.; Cruz, J.; Neveu, V.; Wishart, D.; Manach, C.; et al. Phenol-Explorer 2.0: A major update of the phenol-explorer database integrating data on polyphenol metabolism and pharmacokinetics in humans and experimental animals. Database 2012, 2012, bas031. [CrossRef]

186. Rothwell, J.A.; Perez-Jimenez, J.; Neveu, V.; Medina-Remón, A.; M’hiri, N.; García-Lobato, P.; Manach, C.; Knox, C.; Eisner, R.; Wishart, D.S.; et al. Phenol-Explorer 3.0: A major update of the Phenol-Explorer database to incorporate data on the effects of food processing on polyphenol content. Database 2013, 2013, bat070. [CrossRef]

187. Navarro-González, I.; González-Barrio, R.; García-Valverde, V.; Bautista-Ortín, A.B.; Periago, M.J. Nutritional composition and antioxidant capacity in edible flowers: Characterisation of phenolic compounds by HPLC-DAD-ESI/MSn. Int. J. Mol. Sci. 2015, 16, 805-822. [CrossRef]

188. Chaiyasut, C.; Sivamaruthi, B.S.; Pengkumsri, N.; Sirilun, S.; Peerajan, S.; Chaiyasut, K.; Kesika, P. Anthocyanin profile and its antioxidant activity of widely used fruits, vegetables, and flowers in Thailand. Asian J. Pharm. Clin. Res. 2016, 9, 218-224. [CrossRef]

189. Zheng, J.; Meenu, M.; Xu, B. A systematic investigation on free phenolic acids and flavonoids profiles of commonly consumed edible flowers in China. J. Pharm. Biomed. Anal. 2019, 172, 268-277. [CrossRef]

190. Acikgoz, F.E. Edible flowers. J. Exp. Agric. Int. 2017, 1-5. [CrossRef]

191. Fernandes, L.; Casal, S.; Pereira, J.A.; Saraiva, J.A.; Ramalhosa, E. Edible flowers: A review of the nutritional, antioxidant, antimicrobial properties and effects on human health. J. Food Compos. Anal. 2017, 60, 38-50. [CrossRef]

192. De Morais, J.S.; Sant'Ana, A.S.; Dantas, A.M.; Silva, B.S.; Lima, M.S.; Borges, G.C.; Magnani, M. Antioxidant activity and bioaccessibility of phenolic compounds in white, red, blue, purple, yellow and orange edible flowers through a simulated intestinal barrier. Food Res. Int. 2020, 131, 109046. [CrossRef] [PubMed] 
193. Mlcek, J.; Rop, O. Fresh edible flowers of ornamental plants-A new source of nutraceutical foods. Trends Food Sci. Technol. 2011, 22, 561-569. [CrossRef]

194. Jakobek, L.; Šeruga, M.; Medvidović-Kosanović, M.; Novak, I. Anthocyanin content and antioxidant activity of various red fruit juices. Dtsch. Leb. 2007, 103, 58-64.

195. Smeriglio, A.; Barreca, D.; Bellocco, E.; Trombetta, D. Chemistry, pharmacology and health benefits of anthocyanins. Phyther. Res. 2016, 30, 1265-1286. [CrossRef]

196. Passamonti, S.; Vrhovsek, U.; Vanzo, A.; Mattivi, F. The stomach as a site for anthocyanins absorption from food. FEBS Lett. 2003, 544, 210-213. [CrossRef]

197. Hribar, U.; Poklar Ulrih, N. The metabolism of anthocyanins. Curr. Drug Metab. 2014, 15, 3-13. [CrossRef] [PubMed]

198. Pojer, E.; Mattivi, F.; Johnson, D.; Stockley, C.S. The case for anthocyanin consumption to promote human health: A review. Compr. Rev. Food Sci. Food Saf. 2013, 12, 483-508. [CrossRef]

199. Fang, J. Bioavailability of anthocyanins. Drug Metab. Rev. 2014, 46, 508-520. [CrossRef]

200. Kay, C.D. Aspects of anthocyanin absorption, metabolism and pharmacokinetics in humans. Nutr. Res. Rev. 2006, 19, 137-146. [CrossRef] [PubMed]

201. Blaschek, W. Natural products as lead compounds for sodium glucose cotransporter (SGLT) inhibitors. Planta Med. 2017, 83, 985-993. [CrossRef] [PubMed]

202. Bulgari, R.; Franzoni, G.; Ferrante, A. Biostimulants Application in horticultural crops under abiotic stress conditions. Agronomy 2019, 9, 306. [CrossRef]

203. Rouphael, Y.; Colla, G. Synergistic biostimulatory action: Designing the next generation of plant biostimulants for sustainable agriculture. Front. Plant Sci. 2018, 9, 871. [CrossRef] [PubMed]

204. Tian, S.; Lu, L.; Xie, R.; Zhang, M.; Jernstedt, J.A.; Hou, D.; Ramsier, C.; Brown, P.H. Supplemental macronutrients and microbial fermentation products improve the uptake and transport of foliar applied zinc in sunflower (Helianthus annuus L.) plants. Studies utilizing micro X-ray florescence. Front. Plant Sci. 2015, 5, 808. [CrossRef] [PubMed]

205. Franzoni, G.; Cocetta, G.; Trivellini, A.; Ferrante, A. Transcriptional regulation in rocket leaves as affected by salinity. Plants 2019, 9, 20. [CrossRef]

206. Rouphael, Y.; Cardarelli, M.; Bonini, P.; Colla, G. Synergistic action of a microbial-based biostimulant and a plant derived-protein hydrolysate enhances lettuce tolerance to alkalinity and salinity. Front. Plant Sci. 2017, 8, 131. [CrossRef]

207. Szczałba, M.; Kopta, T.; Gąstoł, M.; Sękara, A. Comprehensive insight into arbuscular mycorrhizal fungi, Trichoderma spp. and plant multilevel interactions with emphasis on biostimulation of horticultural crops. J. Appl. Microbiol. 2019, 127, 630-647. [CrossRef]

208. Santaniello, A.; Scartazza, A.; Gresta, F.; Loreti, E.; Biasone, A.; Di Tommaso, D.; Piaggesi, A.; Perata, P. Ascophyllum nodosum seaweed extract alleviates drought stress in arabidopsis by affecting photosynthetic performance and related gene expression. Front. Plant Sci. 2017, 8, 1362. [CrossRef]

209. Backer, R.; Rokem, J.S.; Ilangumaran, G.; Lamont, J.; Praslickova, D.; Ricci, E.; Subramanian, S.; Smith, D.L. Plant growthpromoting rhizobacteria: Context, mechanisms of action, and roadmap to commercialization of biostimulants for sustainable agriculture. Front. Plant Sci. 2018, 9, 1473. [CrossRef] [PubMed]

210. Carmody, N.; Goñi, O.; Łangowski, Ł.; O'Connell, S. Ascophyllum nodosum extract biostimulant processing and its impact on enhancing heat stress tolerance during tomato fruit set. Front. Plant Sci. 2020, 11, 807. [CrossRef] [PubMed]

211. Hara, M. Potential use of essential oils to enhance heat tolerance in plants. Z. Naturforsch. C. 2020, 75, 225-231. [CrossRef]

212. Mannino, G.; Nerva, L.; Gritli, T.; Novero, M.; Fiorilli, V.; Bacem, M.; Bertea, C.M.; Lumini, E.; Chitarra, W.; Balestrini, R. Effects of different microbial inocula on tomato tolerance to water deficit. Agronomy 2020, 10, 170. [CrossRef]

213. Islam, M.T.; Gan, H.M.; Ziemann, M.; Hussain, H.I.; Arioli, T.; Cahill, D. Phaeophyceaean (Brown Algal) extracts activate plant defense systems in arabidopsis thaliana challenged with phytophthora cinnamomi. Front. Plant Sci. 2020, 11, 852. [CrossRef] [PubMed]

214. Colla, G.; Hoagland, L.; Ruzzi, M.; Cardarelli, M.; Bonini, P.; Canaguier, R.; Rouphael, Y. Biostimulant action of protein hydrolysates: Unraveling their effects on plant physiology and microbiome. Front. Plant Sci. 2017, 8, 2202. [CrossRef]

215. Bulgari, R.; Morgutti, S.; Cocetta, G.; Negrini, N.; Farris, S.; Calcante, A.; Spinardi, A.; Ferrari, E.; Mignani, I.; Oberti, R.; et al. Evaluation of borage extracts as potential biostimulant using a phenomic, agronomic, physiological, and biochemical approach. Front. Plant Sci. 2017, 8, 935. [CrossRef]

216. Casadesús, A.; Polo, J.; Munné-Bosch, S. Hormonal effects of an enzymatically hydrolyzed animal protein-based biostimulant (pepton) in water-stressed tomato plants. Front. Plant Sci. 2019, 10, 758. [CrossRef] [PubMed]

217. Van Eck, N.J.; Waltman, L. Software survey: VOSviewer, a computer program for bibliometric mapping. Scientometrics 2010, 84, 523-538. [CrossRef]

218. Van Eck, N.J.; Waltman, L. VOSviewer manual. Leiden Univ. Leiden 2013, 1, 1-53.

219. Rouphael, Y.; Colla, G. Biostimulants in agriculture. Front. Plant Sci. 2020, 11, 40. [CrossRef] [PubMed]

220. Passafiume, R.; Perrone, A.; Sortino, G.; Gianguzzi, G.; Saletta, F.; Gentile, C.; Farina, V. Chemical-physical characteristics, polyphenolic content and total antioxidant activity of three Italian-grown pomegranate cultivars. NFS J. 2019, 16, 9-14. [CrossRef]

221. Deng, Q.; Xia, H.; Lin, L.; Wang, J.; Yuan, L.; Li, K.; Zhang, J.; Lv, X.; Liang, D. SUNRED, a natural extract-based biostimulant, application stimulates anthocyanin production in the skins of grapes. Sci. Rep. 2019, 9, 2590. [CrossRef] 
222. Pohl, A.; Grabowska, A.; Kalisz, A.; Sekara, A. The eggplant yield and fruit composition as affected by genetic factor and biostimulant application. Not. Bot. Horti Agrobot. Cluj Napoca 2019, 47, 929-938. [CrossRef]

223. Soppelsa, S.; Kelderer, M.; Casera, C.; Bassi, M.; Robatscher, P.; Andreotti, C. Use of biostimulants for organic apple production: Effects on tree growth, yield, and fruit quality at harvest and during storage. Front. Plant Sci. 2018, 9, 1342. [CrossRef] [PubMed]

224. Soppelsa, S.; Kelderer, M.; Testolin, R.; Zanotelli, D.; Andreotti, C. Effect of biostimulants on apple quality at harvest and after storage. Agronomy 2020, 10, 1214. [CrossRef]

225. Gonçalves, B.; Morais, M.C.; Sequeira, A.; Ribeiro, C.; Guedes, F.; Silva, A.P.; Aires, A. Quality preservation of sweet cherry cv. "staccato" by using glycine-betaine or Ascophyllum nodosum. Food Chem. 2020, 322, 126713. [CrossRef]

226. Caruso, G.; El-Nakhel, C.; Rouphael, Y.; Comite, E.; Lombardi, N.; Cuciniello, A.; Woo, S.L. Diplotaxis tenuifolia (L.) DC. Yield and quality as influenced by cropping season, protein hydrolysates, and trichoderma applications. Plants 2020, 9, 697. [CrossRef] [PubMed]

227. Lombardi, N.; Caira, S.; Troise, A.D.; Scaloni, A.; Vitaglione, P.; Vinale, F.; Marra, R.; Salzano, A.M.; Lorito, M.; Woo, S.L. Trichoderma applications on strawberry plants modulate the physiological processes positively affecting fruit production and quality. Front. Microbiol. 2020, 11, 1364. [CrossRef]

228. Roussos, P.A.; Denaxa, N.; Damvakaris, T. Strawberry fruit quality attributes after application of plant growth stimulating compounds. Sci. Hortic. 2009, 119, 138-146. [CrossRef]

229. Kok, D. Grape growth, anthocyanin and phenolic compounds content of early ripening Cv. Cardinal table grape (V. vinifera L.) as affected by various doses of foliar biostimulant applications with gibberellic acid. Erwerbs Obstbau 2018, 60, 253-259. [CrossRef]

230. Parrado, J.; Bautista, J.; Romero, E.J.; García-Martínez, A.M.; Friaza, V.; Tejada, M. Production of a carob enzymatic extract: Potential use as a biofertilizer. Bioresour. Technol. 2008, 99, 2312-2318. [CrossRef]

231. Rodrigues, M.; Baptistella, J.L.C.; Horz, D.C.; Bortolato, L.M.; Mazzafera, P. Organic plant biostimulants and fruit quality-A review. Agronomy 2020, 10, 988. [CrossRef]

232. Ertani, A.; Pizzeghello, D.; Francioso, O.; Sambo, P.; Sanchez-Cortes, S.; Nardi, S. Capsicum chinensis L. growth and nutraceutical properties are enhanced by biostimulants in a long-term period: Chemical and metabolomic approaches. Front. Plant Sci. 2014, 5, 375. [CrossRef]

233. Solverson, P. Anthocyanin bioactivity in obesity and diabetes: The essential role of glucose transporters in the gut and periphery. Cells 2020, 9, 2515. [CrossRef]

234. Wally, O.S.D.; Critchley, A.T.; Hiltz, D.; Craigie, J.S.; Han, X.; Zaharia, L.I.; Abrams, S.R.; Prithiviraj, B. Regulation of phytohormone biosynthesis and accumulation in Arabidopsis following treatment with commercial extract from the marine macroalga Ascophyllum nodosum. J. Plant Growth Regul. 2013, 32, 324-339. [CrossRef]

235. Silva, G.F.P.; Pereira, E.; Melgar, B.; Stojković, D.; Sokovic, M.; Calhelha, R.C.; Pereira, C.; Abreu, R.; Ferreira, I.C.F.R.; Barros, L. Eggplant fruit (Solanum melongena L.) and bio-residues as a source of nutrients, bioactive compounds, and food colorants, using innovative food technologies. Appl. Sci. 2020,11, 151. [CrossRef]

236. Sabatino, L.; Iapichino, G.; Consentino, B.B.; D'Anna, F.; Rouphael, Y. Rootstock and arbuscular mycorrhiza combinatorial effects on eggplant crop performance and fruit quality under greenhouse conditions. Agronomy 2020, 10, 693. [CrossRef]

237. Shahab, M.; Roberto, S.R.; Ahmed, S.; Colombo, R.C.; Silvestre, J.P.; Koyama, R.; de Souza, R.T. Relationship between anthocyanins and skin color of table grapes treated with abscisic acid at different stages of berry ripening. Sci. Hortic. 2020, $259,108859$. [CrossRef]

238. Frioni, T.; Sabbatini, P.; Tombesi, S.; Norrie, J.; Poni, S.; Gatti, M.; Palliotti, A. Effects of a biostimulant derived from the brown seaweed Ascophyllum nodosum on ripening dynamics and fruit quality of grapevines. Sci. Hortic. 2018, 232, 97-106. [CrossRef]

239. Frioni, T.; Tombesi, S.; Quaglia, M.; Calderini, O.; Moretti, C.; Poni, S.; Gatti, M.; Moncalvo, A.; Sabbatini, P.; Berrìos, J.G.; et al Metabolic and transcriptional changes associated with the use of Ascophyllum nodosum extracts as tools to improve the quality of wine grapes (Vitis vinifera cv. Sangiovese) and their tolerance to biotic stress. J. Sci. Food Agric. 2019, 99, 6350-6363. [CrossRef]

240. Blando, F.; Oomah, B.D. Sweet and sour cherries: Origin, distribution, nutritional composition and health benefits. Trends Food Sci. Technol. 2019, 86, 517-529. [CrossRef]

241. Giampieri, F.; Tulipani, S.; Alvarez-Suarez, J.M.; Quiles, J.L.; Mezzetti, B.; Battino, M. The strawberry: Composition, nutritional quality, and impact on human health. Nutrition 2012, 28, 9-19. [CrossRef] [PubMed] 